\title{
Water from abandoned mines as a heat source: practical experiences of open- and closed-loop strategies, United Kingdom
}

\author{
David Banks ${ }^{1,2} \oplus$ - Anup Athresh ${ }^{3,4} \cdot$ Amin Al-Habaibeh $^{3} \cdot$ Neil Burnside $^{1}$
}

Received: 31 August 2016 / Accepted: 15 February 2017 / Published online: 13 April 2017

(C) The Author(s) 2017. This article is an open access publication

\begin{abstract}
Pilot heat pump systems have been installed at two former collieries in Yorkshire/Derbyshire, England, to extract heat from mine water. The installations represent three fundamental configurations of heat exchanger. At Caphouse Colliery, mine water is pumped through a heat exchanger coupled to a heat pump and then discharged to waste (an open-loop heat exchange system). The system performs with high thermal efficiency, but the drawbacks are: (1) it can only be operated when mine water is being actively pumped from the colliery shaft for the purposes of regional water-level management, and (2) the fact that the water is partially oxygenated means that iron oxyhydroxide precipitation occurs, necessitating regular removal of filters for cleaning. At Markham Colliery, near Bolsover, a small amount of mine water is pumped from depth in a flooded shaft, circulated through a heat exchanger coupled to a heat pump and then returned to the same mine shaft at a slightly different depth (a standing column arrangement). This system's fundamental thermal efficiency is negatively impacted by the electrical power required to run the shaft submersible pump,
\end{abstract}

This article is part of the special issue on Sustainable Resource Management: Water Practice Issues.

David Banks

david@holymoor.co.uk

1 School of Engineering, James Watt Building (South), University of Glasgow, Glasgow G12 8QQ, UK

2 Holymoor Consultancy Ltd., 360 Ashgate Road, Chesterfield, Derbyshire S40 4BW, UK

3 Innovative and Sustainable Built Environment Technologies Research Group (iSBET), Nottingham Trent University, Nottingham NG1 4BU, UK

4 Alkane Energy Plc, Edwinstowe House, Edwinstowe, Nottingham NG21 9PR, UK but clogging issues are not significant. In the third system, at Caphouse, a heat exchanger is submerged in a mine water treatment pond (a closed-loop system). This can be run at any time, irrespective of mine pumping regime, and being a closed-loop system, is not susceptible to clogging issues.

Keywords Heat pump $\cdot$ Colliery $\cdot$ Mine water $\cdot$ Green energy $\cdot$ Thermogeology $\cdot$ Iron

\section{Introduction: mine water as a thermal resource}

In active mines, inflowing mine water needs to be removed from the mine system to allow working. This is often achieved in shallow mines by gravity drainage via soughs or adits to nearby valleys or watercourses. In deep mines, active pumping is required. The groundwater removed from the mine is at or somewhat above the annual average soil temperature of the locality in question and increases with depth $\left(1-3{ }^{\circ} \mathrm{C}\right.$ per $100 \mathrm{~m}$ in most tectonically stable areas: Banks 2012). Air must also be circulated carefully through the workings: in winter, the cold downdraught air acquires heat from the rocks as it circulates through the network of tunnels, and the return air is thus warm and can be used for pre-warming machinery or space heating systems.

When a mine is abandoned, one of three hydrological fates typically awaits the mine system:

1. the pumps are switched off and the mine gradually fills with groundwater until it overflows at the surface via a shaft top, an unplugged exploration borehole, a sough, tunnel or adit.

2. the mine continues to be pumped to prevent it filling with water and threatening other working mines downdip (Janson et al. 2009). 
3. the mine, or interconnected mine system, continues to be pumped at one locality (or a limited number of localities) in order to prevent uncontrolled outbreaks of water at the surface (Banks et al. 1997a)

Many (but not all) coal, oil shale and metal deposits contain a significant content of sulphide minerals, such as pyrite $\left(\mathrm{FeS}_{2}\right)$. When exposed to circulating water and oxygen (as is the case in a working mine), these oxidise to form either metal-rich solutions of sulphuric acid, or secondary acidic metal sulphate minerals. These minerals, which may include phases such as jarosite $(\mathrm{K}, \mathrm{Na}, \mathrm{H}) \mathrm{Fe}^{\mathrm{III}}{ }_{3}(\mathrm{OH})_{6}\left(\mathrm{SO}_{4}\right)_{2}$, melanterite $\left(\mathrm{FeSO}_{4} \cdot 7 \mathrm{H}_{2} \mathrm{O}\right)$, römerite $\left(\mathrm{Fe}^{\mathrm{II}} \mathrm{Fe}_{2}{ }^{\mathrm{III}}\left(\mathrm{SO}_{4}\right)_{4} \cdot 14 \mathrm{H}_{2} \mathrm{O}\right)$ or copiapite $\left(\mathrm{Fe}^{\mathrm{II}} \mathrm{Fe}^{\mathrm{III}}{ }_{4}\left(\mathrm{SO}_{4}\right)_{6}(\mathrm{OH})_{2} \cdot 2 \mathrm{H}_{2} \mathrm{O}\right)$, represent a "store" of acidity, metals and sulphate, which can be released into solution when exposed to water, for example, when the mine floods (Bayless and Olyphant 1993; Younger 2000). Thus, the water initially overflowing from abandoned mines is typically rich in dissolved metals (especially iron), sulphate and can be acidic (Banks et al. 1997a, b). These concentrations will often decline with time as the secondary oxidation products are consumed by dissolution (Gzyl and Banks 2007; see also Burrows et al. 2015). Dold (2017) provides a recent thorough review of mineral acidity generating potential. Neglecting the intermediate (secondary mineral) steps, the overall reaction (for pyrite) can be represented by the, admittedly simplified, Eq. (1):

$2 \mathrm{FeS}_{2}+7 \mathrm{O}_{2}+2 \mathrm{H}_{2} \mathrm{O}=2 \mathrm{Fe}^{2+}+4 \mathrm{SO}_{4}{ }^{2-}+4 \mathrm{H}^{+}{ }_{(\text {aq })}$

Following this reaction, the acid may be neutralised by reaction with carbonate or silicate minerals in the host rocks:

$$
\begin{aligned}
& 2 \mathrm{Fe}^{2+}+4 \mathrm{SO}_{4}{ }^{2-}+4 \mathrm{H}^{+}{ }_{(\mathrm{aq})}+4 \mathrm{CaCO}_{3} \\
& =2 \mathrm{Fe}^{2+}+4 \mathrm{SO}_{4}{ }^{2-}+4 \mathrm{Ca}^{2+}+4 \mathrm{HCO}_{3}{ }^{-}
\end{aligned}
$$

Thus, many neutralised mine waters are relatively rich in base cations and bicarbonate alkalinity. In the Coal Measures rocks of the UK, iron-bearing carbonates such as siderite $\left(\mathrm{FeCO}_{3}\right)$ and ankerite $\left(\mathrm{Ca}(\mathrm{Fe}, \mathrm{Mg}, \mathrm{Mn})\left(\mathrm{CO}_{3}\right)_{2}\right)$ can occur (Crook 1912; Hawkes and Smythe 1935; Eden et al. 1957; Lake and Hough 2006), such that this neutralisation reaction can release yet more ferrous iron to solution. If exposed to oxygen, the iron released by Eq. (1) or by iron carbonate dissolution can oxidise to form ferric iron, which is insoluble at all but very low $\mathrm{pH}$ values, precipitating as flocs of iron (III) hydroxide:

$$
\begin{aligned}
& 4 \mathrm{Fe}^{2+}+\mathrm{O}_{2}+4 \mathrm{H}^{+}{ }_{(\mathrm{aq})}+10 \mathrm{H}_{2} \mathrm{O} \\
& =4 \mathrm{Fe}^{3+}+12 \mathrm{H}_{2} \mathrm{O}=4 \mathrm{Fe}(\mathrm{OH})_{3}+12 \mathrm{H}^{+}{ }_{(\text {aq })}
\end{aligned}
$$

The various steps in Eq. (3) are temperature dependent, but experimentation strongly indicates that an increase in temperature (at least in the range $0-35^{\circ} \mathrm{C}$ ) tends to increase the rate of iron oxidation and hydroxide precipitation (Faraldo Sanchez 2007; Raftery 2016).

This ferric (oxy)hydroxide typically imparts an orange coloration to watercourses receiving mine drainage and is commonly known in the mining industry as "ochre" or "yellowboy" or, in stricter mineralogical parlance, limonite. With time, the ferric hydroxide progressively loses water, crystallises and hardens (Grundl and Delwiche 1993). Thus, the terms "ochre" or limonite are non-mineralogically specific and are used to describe a mixture of hydrated iron oxides that may range from amorphous ferric hydroxide $\left(\mathrm{Fe}(\mathrm{OH})_{3}\right)$, through ferrihydrite (metastable nanocrystalline $\mathrm{Fe}_{2} \mathrm{O}_{3}$. $\left(\mathrm{H}_{2} \mathrm{O}\right)_{n}$, where $\left.n=1.8-0.5\right)$ and goethite $(\mathrm{FeOOH})$ to haematite $\left(\mathrm{Fe}_{2} \mathrm{O}_{3}\right)$. For convenience, we will henceforth use the term "ochre" in this article. The ochre settling out on the beds of these watercourses can also smother the benthic fauna that fish feed on, negatively impacting the ecology of the watercourse. Mine waters, their acidity, salt and metal loadings and the ochre issues that follow are typically regarded as an environmental liability. The UK Coal Authority expends considerable effort and financial resources in managing this liability, both in terms of regional pumping of interconnected mine workings, to control mine water levels, and in treating pumped and gravity discharges of mine water (Banks and Banks 2001).

However, these mine water discharges can be viewed as a "green" renewable energy asset. Their temperature renders them suitable for space heating (via the use of heat pump technology) in the winter and as a heat sink for space cooling in the summer. The enormous volumes of mine workings and highly transmissive nature of mine roadways imply that the thermal storage associated with such workings is substantial and that very large water yields (several tens or even hundreds of $\mathrm{L} \mathrm{s}^{-1}$ ) can be abstracted from open flooded roadways and shafts. Simply by extracting a few ${ }^{\circ} \mathrm{C}$ of heat from a flow of, say, $50 \mathrm{~L} \mathrm{~s}^{-1}$ of mine water can result in MW-scale quantities of thermal potential:

Heat power available $=Q \cdot \Delta T \cdot \rho_{\mathrm{w}} \cdot c_{\mathrm{w}}$

Example:50 $\mathrm{L} \mathrm{s}^{-1} \times 4{ }^{\circ} \mathrm{C} \times 4190 \mathrm{~J} \mathrm{~L}^{-1{ }^{\circ}} \mathrm{C}^{-1}$

$$
=838,000 \mathrm{~J} \mathrm{~s}^{-1}=0.838 \mathrm{MW} \text {, }
$$

where $Q=$ mine water flow in $\mathrm{L} \mathrm{s}^{-1}$ (say, $50 \mathrm{~L} \mathrm{~s}^{-1}$ ), $\Delta T=$ temperature change at heat exchanger in ${ }^{\circ} \mathrm{C}$ (say, $\left.4^{\circ} \mathrm{C}\right), \rho_{\mathrm{w}}=$ density $\left(\mathrm{kg} \mathrm{L}^{-1}\right)$ and $c_{\mathrm{w}}=$ specific heat capacity $\left(\mathrm{J} \mathrm{kg}^{-1}{ }^{\circ} \mathrm{C}^{-1}\right)$ of water and hence, $\rho_{\mathrm{w}} \times c_{\mathrm{w}}=$ volumetric heat capacity of water $\left(\mathrm{J} \mathrm{L}^{-1}{ }^{\circ} \mathrm{C}^{-1}\right)=$ c. $4190 \mathrm{~J} \mathrm{~L}^{-1}{ }^{\circ} \mathrm{C}^{-1}$.

Such mine water-based heating schemes have been operational at a number of locations globally for 
Fig. 1 Overview map of Britain and Ireland, showing mine water heat pump schemes. Egremont (Banks et al. 2017) is based on an ironstone (haematite) mine, while the rest are coal mines

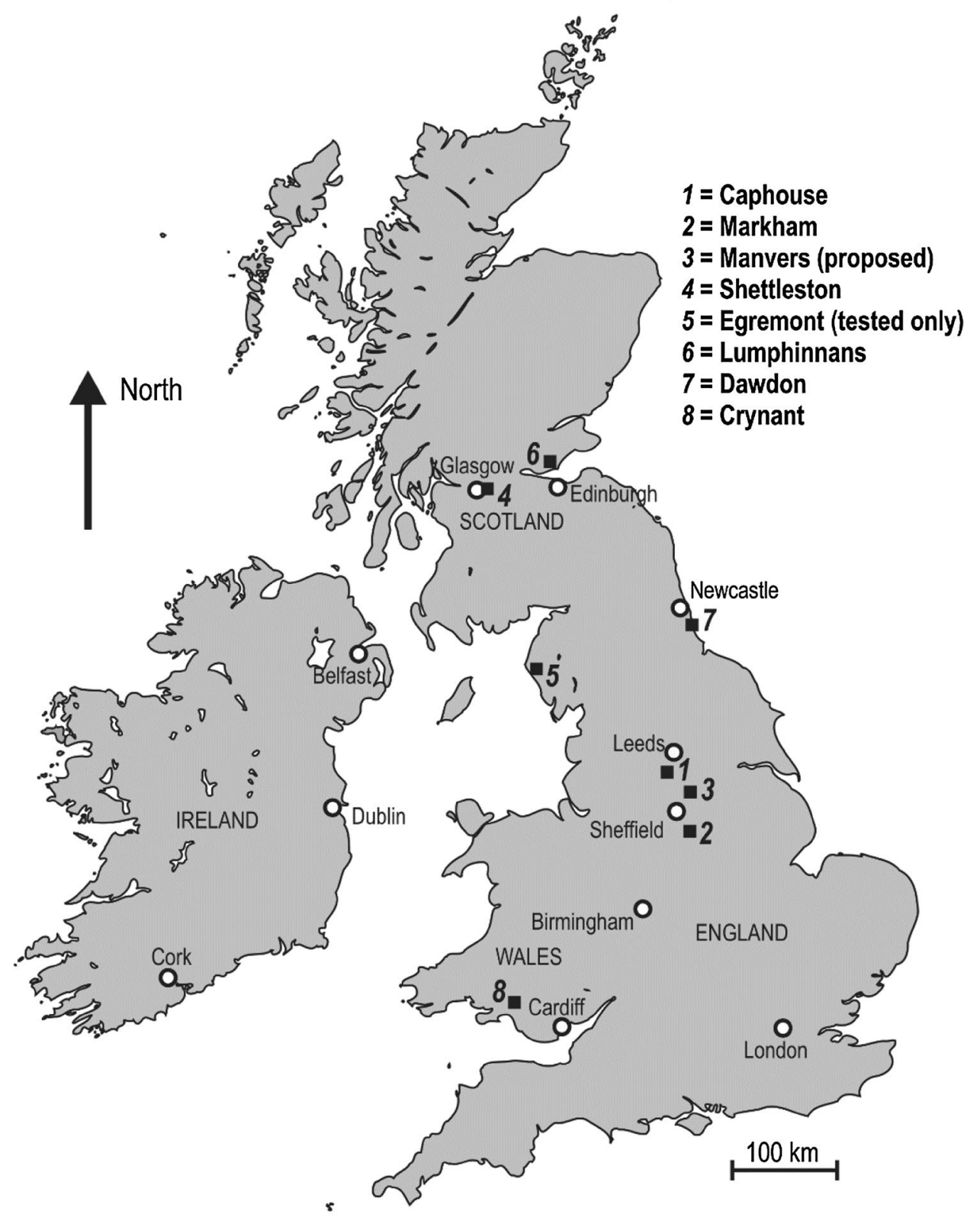

several decades. Amongst the best known of these are the schemes at Springhill, Nova Scotia, Canada (Jessop 1995; Jessop et al. 1995; Michel 2009; Tweedie 2014), Park Hills, Missouri, USA (Watzlaf and Ackman 2006; DOE 2015), Marywood University, Pennsylvania, USA (Korb 2012), several in Saxony, Germany (Ramos et al. 2015) and megawatt-scale schemes at Barredo colliery, Mieres, northern Spain (Loredo et al. 2011, 2017; Ordóñez et al. 2012; Jardón et al. 2013) and at Heerlen, Netherlands (Minewater Project 2008; Ferket et al. 2011; Verhoeven et al. 2014). More recently, schemes have been documented in Eastern Europe, including those at Saturn colliery, Czeladz, Poland (Malolepszy et al. 2005; Tokarz and Mucha 2013) and Novoshakhtinsk colliery, Russia
(Rostov Regional Government 2011; Ramos et al. 2015). A number of mine water heat pump schemes are also active in the United Kingdom (Fig. 1). Global reviews are provided by Banks et al. (2003, 2004), Watzlaf and Ackman (2006), Hall et al. (2011), Preene and Younger (2014), Ramos et al. (2015) and Bracke and Bussmann (2015).

\section{Obstacles to the uptake of mine water heating and cooling}

Banks (2016) listed several main obstacles to the uptake of mine water space heating and cooling, with an emphasis on the UK. 
- Perceived risk of ochre clogging of pumps, heat exchangers, pipelines and reinjection wells.

- Risk of reinjected thermally spent (e.g. cool) water "breaking through" open mine pathways to the (e.g. warm) abstraction shaft or well.

- Uncertainty over legal and licencing issues-including the guaranteed longevity of mine pumping operations and abstraction licences, and the legal risk of accruing future liability for mine water pollution.

- Presence of a suitably dense long-term heating and cooling demand, with suitable heat emitters, in the vicinity of the mine. If this is associated with a new development, are conventional heating/cooling solutions already "locked in"?

To these can probably be added the difficulties of identifying suitable ownership, economic and distribution models: will an operator simply distribute mine water (or a fluid thermally coupled to the mine water) to individual consumers, each with their own heat pump? Or will an operator own a centralised heat pump plant room and a district heating and cooling network? In each case, where do ownership boundaries and responsibilities fall, and who owns the right to claim any state subsidies?

The EU Research Fund for Coal and Steel has funded a project entitled "Low Carbon Afterlife: Sustainable Use of Flooded Coal Mine Voids as a Thermal Energy Source-a Baseline Activity for Minimising Post-Closure Environmental Risks" (acronym: LoCAL; Gzyl et al. 2016), with several work packages, each specifically aimed at overcoming these barriers. The work reported in this paper specifically addresses the design and operation of heat exchange solutions to understand and minimise hydrogeochemical risks. Internationally, the Barredo shaft heat pump scheme at Mieres, northern Spain (Loredo et al. 2017), and the proposed Ewa shaft heat pump scheme at the Szombierki coal mine, Bytom, Poland (Janson et al. 2016), are included as LoCAL study sites, together with a number of schemes in the United Kingdom. The paper will examine, in turn, the British LoCAL study sites and summarise the experiences to date with each site.

\section{Modes of operation for mine water heat pump/ exchange schemes}

There are a number of modes in which heat can be exchanged with mine water (Fig. 2, using terminology consistent with Banks et al. 2004; Banks 2012):
Open-loop systems with disposal of thermally spent water

Here, mine water is abstracted from a flooded mine via a shaft or boreholes and passed directly through a heat pump or (more commonly) a heat exchanger (coupled to a heat pump). After heat exchange, the mine water is rejected to surface water (or, sometimes, to the sea), often following some form of treatment (Fig. 2a). Examples of such schemes include the Barredo coal mine shaft at Mieres, Asturias, northern Spain (Loredo et al. 2011, 2017; Ordóñez et al. 2012; Jardón et al. 2013), where the water quality is relatively good and where no treatment is necessary, and the Caphouse colliery in Yorkshire, UK, (Burnside et al. 2016a), where heat exchange takes place prior to mine water treatment. Possible disadvantages of such open-loop schemes include: the cost of treatment and the potential for pumps, pipelines, heat exchangers and reinjection boreholes to become fouled with chemical precipitates (often iron oxyhydroxides-'ochre' - or manganese oxides).

\section{Open-loop systems with reinjection of thermally spent water}

If treatment and disposal of mine water to surface waters is to be avoided, it is possible to reinject the water back into the mine workings, or to another aquifer unit, following heat exchange (Fig. 2b). The advantage of this is that water resources are conserved while treatment and disposal costs are avoided. On the other hand, it requires the drilling and maintenance of reinjection boreholes and runs the risk of thermal "feedback" if the connection between the abstraction and injection points is too direct. Examples of this type of scheme include Shettleston, Glasgow and Lumphinnans, Fife, Scotland (Banks et al. 2009) and Heerlen (Minewater Project 2008; Ferket et al. 2011; Verhoeven et al. 2014). In the latter scheme, the reinjected cool water (from heating) or warm water (from cooling operations) could theoretically be stored in the mine workings, allowing for later abstraction during the appropriate season.

\section{Closed-loop systems}

Here, a heat exchanger (which may be a steel radiator, or a loop of polythene pipe) is submerged in the mine water. This may take place in the mine itself (in a flooded shaft or gallery, Fig. 2c), as at Folldal mine in Norway (Banks et al. 2004; Ramos et al. 2015), or within a mine water treatment lagoon, after the mine water has been pumped to the surface, as at Caphouse, Yorkshire, UK (Fig. 2d, Burnside et al. 2016a). A heat transfer fluid is circulated through the heat exchanger, typically back to a heat pump servicing 
Fig. 2 Different modes of heat extraction from/rejection to abandoned, flooded mines. a Open loop with disposal of water to surface recipient, $\mathbf{b}$ open loop with reinjection, $\mathbf{c}$ closed loop in flooded shaft, d closed loop in surface mine water treatment pond, e standing column with bleed and recirculation in shaft, $\mathbf{f}$ standing column configuration, with large natural flow up shaft. $H E$ heat exchanger or heat pump, $H P$ heat pump. Reproduced with the permission of $(C$ David Banks
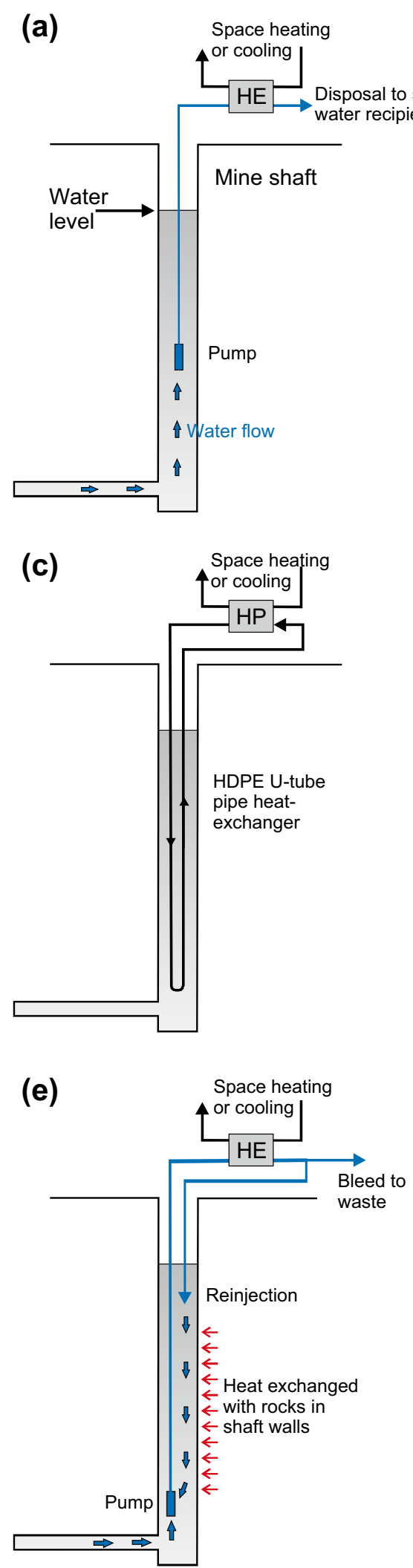
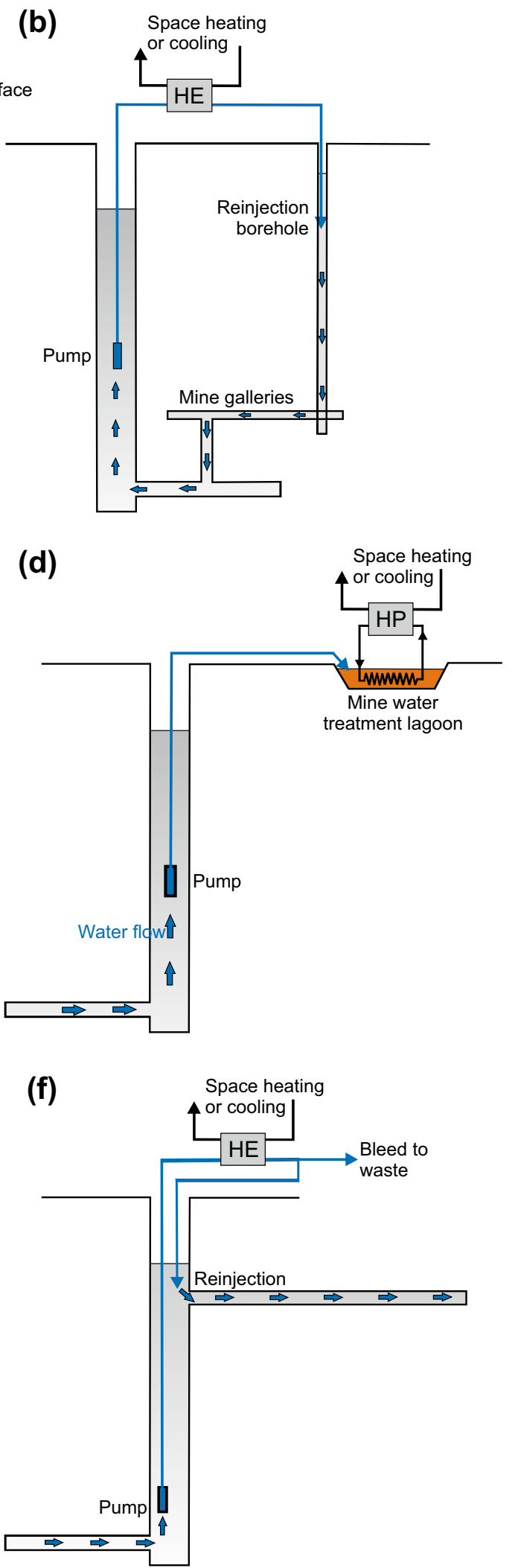

a space heating/cooling demand. The main advantage of this system is that no mine water is abstracted and all issues relating to water chemistry and treatment are thus avoided. The main disadvantage is that, because mine water is not necessarily being deliberately mobilised by pumping, replenishment of heat to the heat exchanger takes place 
by conduction, natural advection and thermal convection of water in the mine void. The heat yield of closed-loop systems is thus often more limited than with open-loop systems.

\section{"Standing column" systems}

Here, water is abstracted from a specific depth in a mine shaft. It is passed through a heat exchanger and some or all of the water is returned to the same shaft at a different depth and different temperature (Fig. 2e). Any fraction that is not returned, but which is disposed of at surface, is known as the bleed fraction (if the bleed fraction is $100 \%$, it is simply an open-loop system with disposal). The returned water usually flows along the shaft towards the pump, absorbing heat from (or, if warmer, rejecting heat to) the walls of the shaft. If there is no natural advection of water along the shaft, the heat gain is ultimately sourced from conduction through the surrounding rocks towards the walls of the shaft, and the sustainable heat yield will usually be rather limited (Fig. 2e). If there is natural water advection along the shaft, this will tend to thermally replenish the system, increasing the heat yield. If the natural advection along the shaft is very large, the reinjected water may flow away from the shaft before returning to the pump, effectively becoming decoupled from the pumping horizon (Fig. 2f).

\section{British LoCAL study sites}

In the United Kingdom, the LoCAL project monitors three coal mine study sites, representing each of the configurations listed above:

1. The Markham No. 3 shaft study site near Bolsover-a standing column system.

2. The Caphouse site, near Wakefield, which incorporates an open-loop mine water system with disposal to treatment lagoons, and

3. a closed-loop system installed in a mine water treatment pond.

4. The Shettleston site, a long-established, operational open-loop mine water system, with reinjection of thermally spent water.

At the Markham and Caphouse sites, monitoring systems have been implemented to evaluate the energetic performance of the heat pump schemes, by the installation of heat meters on the mine water and delivery sides of the heat pump, together with the monitoring of electrical power consumption. Furthermore, the hydrochemistry of the mine water is monitored on an approximate monthly basis, with the following parameters determined in the field: $\mathrm{pH}$, dissolved $\mathrm{O}_{2}$, Eh, total alkalinity, temperature, electrical conductivity and samples being collected for laboratory analysis of suites of major cations and anions, ${ }^{2} \mathrm{H},{ }^{18} \mathrm{O}$ and ${ }^{34} \mathrm{SO}_{4}=$ stable isotopes and (more recently) dissolved methane. The detailed hydrochemistry of the two sites is fully documented by Burnside et al. (2016a, b).

In addition to these, a fourth study site, at the former Manvers Colliery, near Barnsley, South Yorkshire, is under development as a future open-loop system, with abstraction from, and reinjection to, two different levels of coal mine workings. This will not be discussed further in this paper as it is not yet fully operational (being at the permitting and licencing stage).

\section{Caphouse, Yorkshire: open-loop system with discharge to surface water}

Caphouse Colliery is located c. $9 \mathrm{~km}$ WSW of the town of Wakefield in West Yorkshire. It comprises several shafts including the Hope $\left(1.6254^{\circ} \mathrm{W} 53.6418^{\circ} \mathrm{N}\right)$, Inman, Furnace and Caphouse $\left(1.6182^{\circ} \mathrm{W} 53.6440^{\circ} \mathrm{N}\right)$ shafts and two drifts (Brown and Goodchild 1979; Kruse 2007). The colliery complex closed as a working mine in 1985, but has now been reopened as the National Coal Mining Museum of England (NCMME). Caphouse/Hope colliery is hydraulically interconnected underground to a wider network of collieries, including the workings of the Woolley $\left(1.5338^{\circ} \mathrm{W} 53.5961^{\circ} \mathrm{N}\right)$ and Denby Grange Collieries $\left(1.5942^{\circ} \mathrm{W} 53.6340^{\circ} \mathrm{N}\right)$ (INWATCO 2005a, b). The Hope Shaft is pumped every night and early morning (while electricity is cheap) to maintain mine water levels sufficiently low that (a) the museum's underground exhibits and visitor galleries do not flood and (b) to prevent uncontrolled outbreaks of ochreous mine water on a regional basis. The Hope Shaft is some $197 \mathrm{~m}$ deep and the submersible pumps are placed at c. $170 \mathrm{~m}$ depth $\left(-23 \mathrm{~m}\right.$ as $\left.1^{1}\right)$, with mine water levels in the shaft being maintained in the range c. 143-156 $\mathrm{m} \mathrm{bgl}^{2}$ (+4 to $-9 \mathrm{~m}$ asl). The average pumping rate is some $3000 \mathrm{~m}^{3}$ day $^{-1}$ (up to $76 \mathrm{~L} \mathrm{~s}^{-1}$ for $\left.12-16 \mathrm{~h} \mathrm{day}^{-1}\right)$. The mine water is treated in a passive aerobic aeration-settlement-wetland system, comprising an aeration cascade (with optional alkali dosing), two aeration basins, a balancing pond, four settlement basins $(2 \times 2$ in parallel) and two parallel polishing reed beds, prior to discharge to the local stream (PIRAMID 2003, Banks 2007; Faraldo Sanchez 2007-Fig. 3).

\footnotetext{
1 Above sea level.

${ }^{2}$ Below ground level.
} 
Fig. 3 Overview map of Caphouse Colliery site, showing (schematically) the pumped mine water flow through the aerobic treatment system. $H P$ heat pump cabin, $A l 1$ st aeration pond with aeration cascade at southern end, $A 2$ 2nd aeration pond, B balancing pond, $S$ sedimentation basins, $R 1$ and $R 2$ reed beds, $O$ outfall of treated mine water to stream. 1-4 installed water-level/temperature loggers

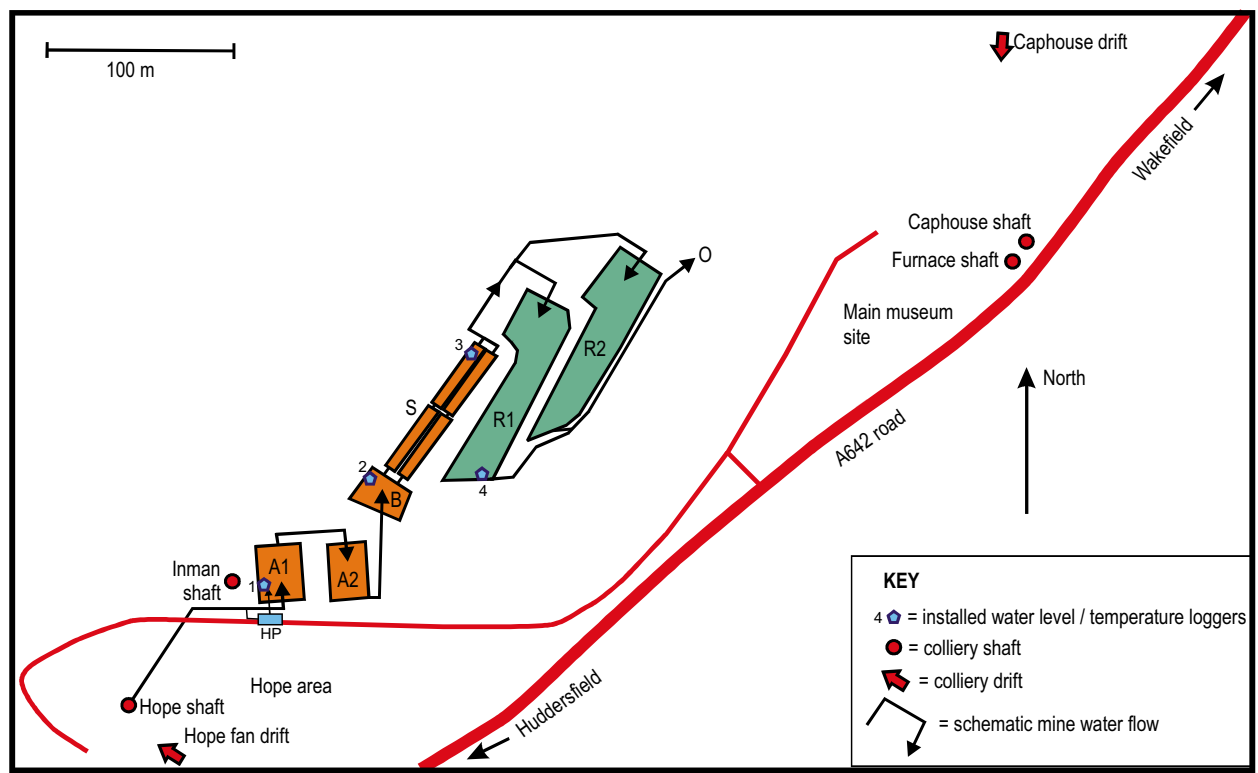

The water is pumped from the mine at typically slightly above $14{ }^{\circ} \mathrm{C}$ (although temperatures of down to $12^{\circ} \mathrm{C}$ have historically been recorded). Presupposing the removal of $5^{\circ} \mathrm{C}$ of heat via a heat exchange system, a flow rate of $3000 \mathrm{~m}^{3}$ day $^{-1}$ represents a potential heat yield of:

$$
\begin{aligned}
& 3,000,000 \mathrm{~L} \mathrm{day}^{-1} \times 5 \mathrm{~K} \\
& \times 4.19 \mathrm{~kJ} \mathrm{~L}^{-1} \mathrm{~K}^{-1} / 86400 \mathrm{~s} \mathrm{day}^{-1}=730 \mathrm{~kW}
\end{aligned}
$$

Thus, a pilot space heating plant has been set up at Caphouse, based on a Vaillant Geotherm VWS 101/2 heat pump of nominal $10.5 \mathrm{~kW}$ heat output. This provides space heating (via a buffer tank and thence circulation of warm water through a conventional space heating radiator, with a flow temperature of $50-52{ }^{\circ} \mathrm{C}$ and a return of $45-46^{\circ} \mathrm{C}$ ) to a museum audiovisual exhibit in the building associated with the Inman shaft. A small portion of the pumped mine water is taken from the main pipeline between the Hope Shaft and the first aeration lagoon. This mine water offtake passes through a dual in-line mesh filter and then through two parallel (one operational, one standby) shell and tube heat exchangers before being discharged to the first aeration lagoon. Heat is transferred via the heat exchangers to a $20 \%$ solution of Hydratech Thermox FPG heat transfer fluid (based on propylene glycol), which is circulated through the heat pump evaporator (Fig. 4).

The water chemistry of the Hope Shaft mine water has been described in full detail by Burnside et al. (2016a) and will only be summarised here, with a representative analysis being presented in Table 1 . The water is typically a sodium sulphate-(bicarbonate) water, which is likely to have formed by the mixture of an acid sulphate signature (derived from pyrite oxidation in the mined strata), with an ambient sodium bicarbonate water (which is typical of the deep British Coal Measures strata-Banks 1997; Banks et al. 1997b). During the past decade or so of pumping from Hope Shaft, the quality of the mine water has improved, with iron concentrations decreasing from c. 30 to c. $15 \mathrm{mg} \mathrm{L}^{-1}$, and sulphate concentrations declining from c. 1200 to c. $600 \mathrm{mg} \mathrm{L}^{-1}$. Since early 2015 , the chloride concentrations increased to over $300 \mathrm{mg} \mathrm{L}^{-1}$ for reasons which are still not wholly clear. The Caphouse water consistently yields analyses of total iron somewhat higher than dissolved/ferrous iron (see Table 1), implying that oxidation of dissolved ferrous iron has commenced already in the workings or in the shaft. Indeed,

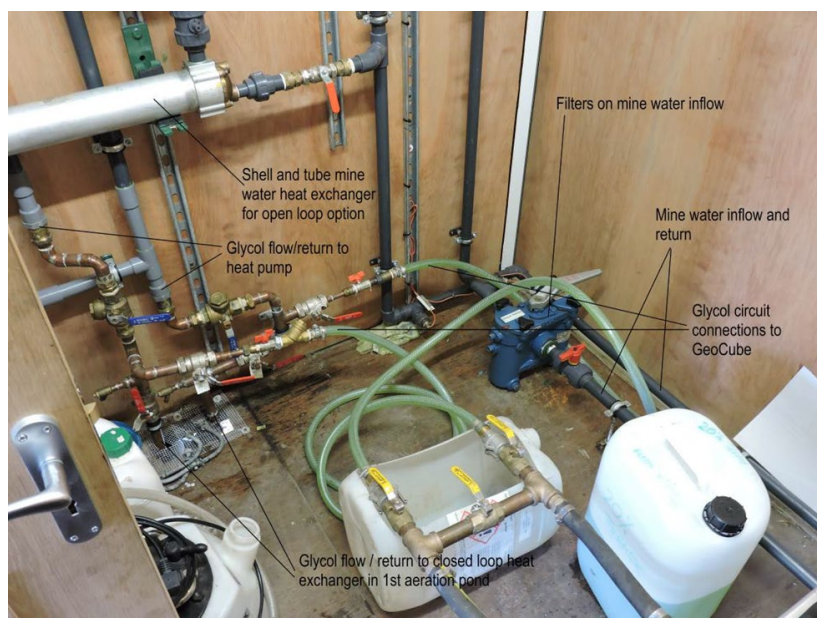

Fig. 4 Interface for open-loop (mine water circuit) and closed-loop options in Caphouse heat pump cabin. Optional couplings to GeoCube $^{\mathrm{TM}}$ thermal response test rig also shown 
Table 1 Characteristic water analyses from the LoCAL study sites' mine waters

\begin{tabular}{|c|c|c|c|c|}
\hline & Shettleston & Caphouse & Markham regime 1 & Markham regime 2 \\
\hline Field determinations & $11 / 2 / 16$ & $27 / 4 / 16$ & & $27 / 4 / 16$ \\
\hline Temperature, ${ }^{\circ} \mathrm{C}$ & 11.2 & 13.6 & $15.4^{\mathrm{c}}$ & 13.3 \\
\hline $\mathrm{pH}$ & 7.14 & 6.87 & & 7.33 \\
\hline Dissolved oxygen, $\%$ saturation & $21.8 \%^{\mathrm{a}}$ & $18 \%$ & & $86 \%$ \\
\hline Electrical conductivity, $\mu \mathrm{S} \mathrm{cm}^{-1}$ & 915 & 2733 & & 2268 \\
\hline Redox potential, $\mathrm{mV}$ & $+19^{\mathrm{a}}$ & -35 & & +79 \\
\hline Alkalinity, meq $\mathrm{L}^{-1}$ & 6.80 & 7.59 & & 5.04 \\
\hline Dissolved gases & $11 / 2 / 16$ & $27 / 4 / 16$ & $15 / 10 / 12$ & $27 / 4 / 16$ \\
\hline $\mathrm{CO}_{2}, \mathrm{mg} \mathrm{L}^{-1}$ & nd & $169^{\mathrm{b}}$ & nd & $20.8^{\mathrm{b}}$ \\
\hline $\mathrm{CH}_{4}, \mu \mathrm{g} \mathrm{L}^{-1}$ & nd & $495^{\mathrm{b}}$ & 9040 & $16.5^{\mathrm{b}}$ \\
\hline Cations & $11 / 2 / 16$ & $26 / 9 / 14$ & $15 / 10 / 12$ & $17 / 9 / 15$ \\
\hline $\mathrm{Ca}, \mathrm{mg} \mathrm{L}^{-1}$ & 92 & 77 & 435 & 130 \\
\hline $\mathrm{Mg}, \mathrm{mg} \mathrm{L}^{-1}$ & 37 & 47 & 218 & 43 \\
\hline $\mathrm{Na}, \mathrm{mg} \mathrm{L}^{-1}$ & 36 & 417 & 3690 & 434 \\
\hline $\mathrm{K}, \mathrm{mg} \mathrm{L}^{-1}$ & 5.3 & 9 & 110 & 26 \\
\hline $\mathrm{Fe}$ (dissolved), $\mathrm{mg} \mathrm{L}^{-1}$ & 0.79 & 14.1 & $19.2-19.7$ & $0.13-0.16$ \\
\hline $\mathrm{Fe}$ (total), $\mathrm{mg} \mathrm{L}^{-1}$ & 1.62 & 16.5 & 21.5 & 0.72 \\
\hline $\mathrm{Mn}, \mu \mathrm{g} \mathrm{L}^{-1}$ & 214 & 660 & 3410 & 27 \\
\hline Ammoniacal-N, mg L ${ }^{-1}$ & nd & 1 & 5.0 & $<0.01$ \\
\hline $\mathrm{Ba}, \mu \mathrm{g} \mathrm{L}{ }^{-1}$ & 74 & 10 & 150 & 120 \\
\hline $\mathrm{Sr}, \mu \mathrm{g} \mathrm{L}^{-1}$ & 475 & 710 & 5440 & 1040 \\
\hline Anions & $11 / 2 / 16$ & $26 / 9 / 14$ & $15 / 10 / 12$ & $17 / 9 / 15$ \\
\hline $\mathrm{Cl}^{-}, \mathrm{mg} \mathrm{L}^{-1}$ & 65.4 & 136 & 6590 & 829 \\
\hline $\mathrm{SO}_{4}=\mathrm{mg} \mathrm{L}^{-1}$ & 58.1 & 640 & 1723 & 135 \\
\hline Alkalinity, meq $\mathrm{L}^{-1}$ & nd & 9.57 & 8.69 & 6.25 \\
\hline $\mathrm{NO}_{3}^{-}, \mathrm{mg} \mathrm{L}^{-1}$ & 0.54 & nd & nd & $3.1(10 / 9 / 15)$ \\
\hline $\mathrm{F}^{-}, \mathrm{mg} \mathrm{L}^{-1}$ & $<0.5$ & nd & nd & nd \\
\hline $\mathrm{Br}^{-}, \mathrm{mg} \mathrm{L}^{-1}$ & 0.08 & nd & nd & nd \\
\hline
\end{tabular}

Electrical conductivity is cited in $\mu \mathrm{S} \mathrm{cm}^{-1}$, where $1 \mathrm{~S}=1 \mathrm{ohm}^{-1}=1 \mathrm{mho}$ $n d$ not determined

${ }^{a}$ Dissolved oxygen and redox potential may be overestimated due to difficulties in avoiding contact with atmospheric oxygen during measurement

${ }^{b}$ Determined by analysis by British Geological Survey of samples collected in stainless steel gas-tight 'bombs'

${ }^{\mathrm{c}}$ Typical value based on Athresh et al. (2015) an underground inspection of the over-water-table workings reveals plenty of opportunities for partial oxidation of a portion of the mine water cascading into the dewatered upper workings.

One of the drawbacks of the open-loop scheme is that it can, of course, only be used when mine water is being pumped from Hope Shaft (i.e. night time and early morning, when electricity is cheapest). The filters prior to the heat exchangers require regular cleaning of ochre deposits by museum staff, reportedly up to several times each day (Fig. 5). Despite the filters becoming clogged, however, there have not been major issues with clogging of the shell and tube heat exchangers with ochre deposits, an observation which lends weight to the assertion by staff (HUNOSA pers. comm.; Loredo et al. 2017) of the Barredo/Mieres heat pump scheme in Asturias, Spain, that shell and tube heat exchangers are less susceptible to ochre clogging than parallel plate heat exchangers.

Athresh et al. (2016) reports on the performance of the Caphouse open-loop scheme, as measured by (1) a Kampstrup 602 Multical heat meter measuring the thermal energy supplied from the heat pump to a thermal buffer tank, (2) an identical heat meter measuring the amount of thermal energy extracted from the mine water and (3) an 'Autometer' A100MT electric meter measuring the electrical power consumed by the heat pump unit. He reports that the heat pump (not including the electricity consumption of the shaft submersible pump, as this must be operated in 

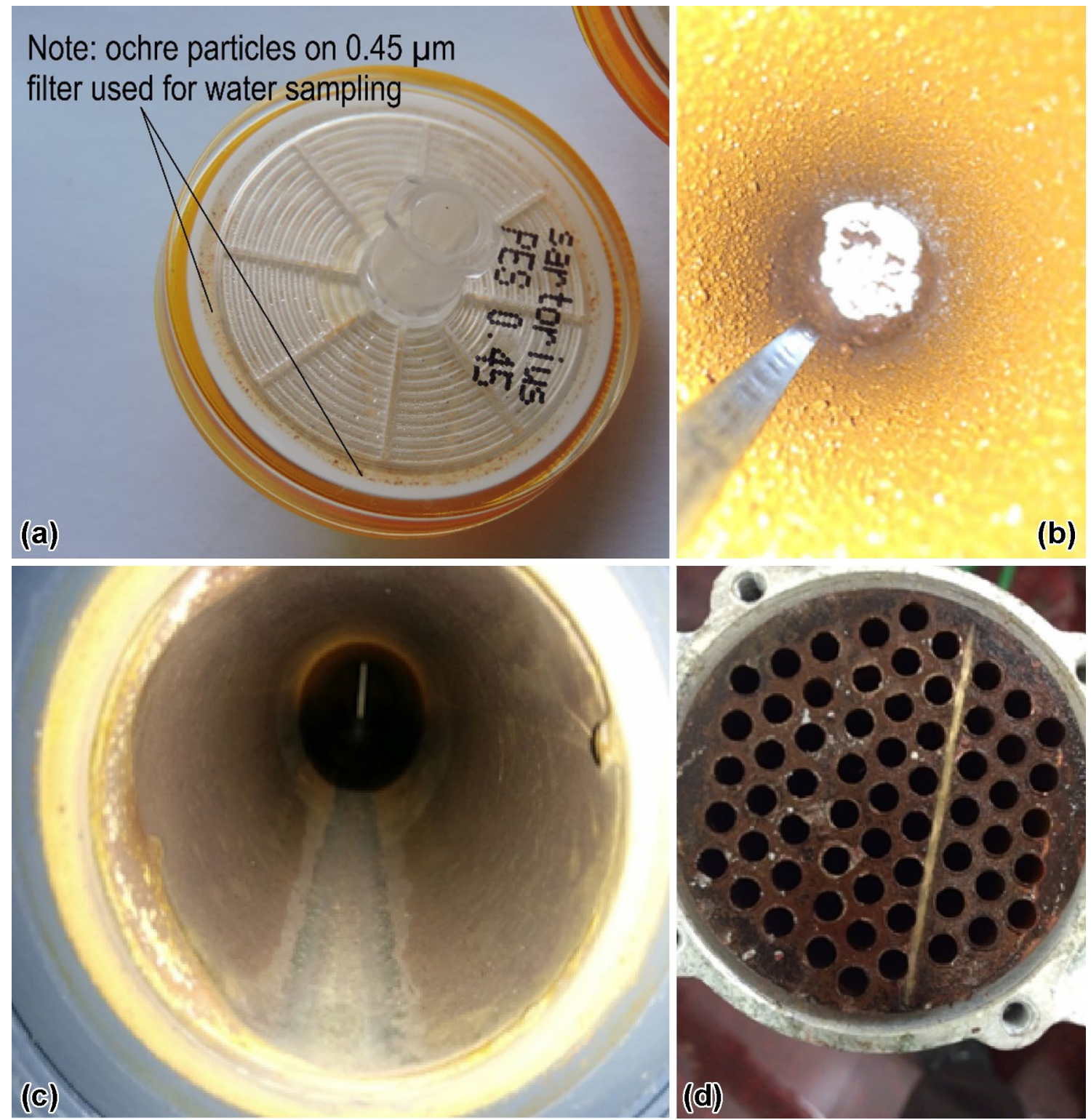

Fig. 5 a A $0.45 \mu \mathrm{m}$ filter used for water sampling at Shettleston. Note the many small ochreous particles retained on the filter; $\mathbf{b}$ the interior of a mine water strainer from Caphouse (significant ochre accretion), after 4 days' operation; $\mathbf{c}$ the interior of a mine water pipe from Markham and $\mathbf{d}$ shell and tube heat exchanger (from Markham), both after 2.5 years' operation (no ochre accretion) any case for dewatering purposes) exhibits a coefficient of performance (ratio of useful heat supplied to buffer tank to electricity consumed by heat pump) varying from 3.5 to 4.0, with a mine water inflow temperature of around $14.5^{\circ} \mathrm{C}$ and a temperature differential across the mine water heat exchangers of $5-6^{\circ} \mathrm{C}$.

\section{Shettleston, Glasgow: open-loop system with reinjection}

Shettleston $\left(4.1669^{\circ} \mathrm{W} 55.8501^{\circ} \mathrm{N}\right)$ is amongst the oldest of Britain's mine water heat pump schemes, having been commissioned in 1999 to provide space heating and pre-heating of domestic hot water to 16 social housing apartments in eastern Glasgow, Scotland. The early operation of the scheme was documented by Banks et al. (2009). In principle, the scheme abstracts mine water from a borehole (reported to be up to c. $100 \mathrm{~m}$ deep) with a submersible pump, passes the water directly through the evaporators of two heat pumps and then returns the thermally spent water to a shallower reinjection borehole situated some $37 \mathrm{~m}$ away. The abstraction borehole is believed to penetrate abandoned workings, probably of the Ell or possibly the slightly deeper Glasgow Main, Splint or Virgin seams (Burke 1998). It is not wholly clear whether the injection 
borehole returns water to a higher level of mine workings or simply to permeable horizons in the Carboniferous (Westphalian) Coal Measures aquifer sequence. The heat pumps currently employed are two Danfoss BW10-025 units each of nominal $31-34 \mathrm{~kW}$ heating capacity (for a nominal water inlet temperature of $10^{\circ} \mathrm{C}$ ).

To date, the system has run with relatively few operational problems and few issues with clogging of the evaporator heat exchangers themselves have been experienced. The water chemistry is normally similar to a rather conventional calcium bicarbonate groundwater and is rather low in dissolved iron. The fact that total iron is around double the dissolved iron in the analysis of Table 1, together with the observation of small ochre particles on sample filters, suggests that the iron in the water is already partially oxidised underground to form small ochre flocs (Fig. 5). It is reported that the mine water can episodically become very ochreous, as if iron oxyhydroxide particles are being flushed out of the mine system. It is suspected, but not yet established, that these episodes may be related to high rainfall episodes. The ochreous episodes can lead to inline filters becoming clogged on the water supply line to the heat pump, resulting in head loss and the necessity for regular clearance. Furthermore, the reinjection borehole has reduced in capacity with time and currently a proportion of the spent water is run to waste at surface rather than being reinjected. The Shettleston site has only recently been incorporated into the LoCAL project and hence available data are very limited and the site will not be discussed further in detail.

\section{Markham No. 3, Derbyshire: "standing column" system}

Markham Colliery, located just north of Bolsover, Derbyshire, UK, comprises four main shafts. The site $\left(1.3285^{\circ} \mathrm{W}\right.$ $53.2424^{\circ} \mathrm{N}$ ) of the two southern shafts (shafts nos. 2 and 3) is now occupied by a short-term operating reserve (STOR) gas engine electricity generation station, operated by the firm Alkane Ltd., and supplying peak load electricity to the National Grid to augment the electricity supply whenever a high demand or a reduction in conventional electricity supply is anticipated. Since 1904, Markham colliery worked coal from a number of seams of the Westphalian Lower and Middle Coal Measures strata (Sheppard 2005).

Markham No. 3 shaft is the only one of the shafts that has not been backfilled, following abandonment in around 1993. The shaft was brick-lined at $15 \mathrm{ft}(4.6 \mathrm{~m})$ diameter and was reportedly c. $490 \mathrm{~m}$ deep (healeyhero 2015), although shafts 1 and 4 , with which shaft 3 interconnected, reached the Blackshale coal at c. $630 \mathrm{~m}$ deep (Burnside et al. 2016b). As at Caphouse (above), Markham colliery is a part of a wider network of hydraulically interlinked abandoned collieries, including those at Arkwright $\left(53.2296^{\circ} \mathrm{N} 1.3633^{\circ} \mathrm{W}\right)$, Bolsover $\left(53.2350^{\circ} \mathrm{N} 1.3116^{\circ} \mathrm{W}\right)$, Duckmanton $\left(53.2447^{\circ} \mathrm{N} 1.3521^{\circ} \mathrm{W}\right)$ and Ireland, Staveley $\left(53.2626^{\circ} \mathrm{N} 1.3456^{\circ} \mathrm{W}\right)$. Markham No 3 Shaft was left largely open, following abandonment, with a hydraulically open plug at the level of the Ell seam $(-357 \mathrm{~m}$ asl), to allow venting of mine gas. This gas was initially used to power the gas engines at the Alkane site. However, as mine water levels rose following the post-abandonment cessation of pumping, the methane yield declined as methane-rich horizons became submerged. Deliberate methane abstraction ceased in 2006, and now imported gas is used to fuel the gas engine generators, although water levels in the shaft continue to rise. To give some impression of the rate of rise, in May 2011, the water level was $239.5 \mathrm{~m} \mathrm{bgl}$ $(-167.7 \mathrm{~m}$ asl $)$, while by February 2016 it was at $136 \mathrm{~m} \mathrm{bgl}$ (Fig. 6).

In 2012, Alkane started trialling a pilot heat pump project based on mine water from No. 3 shaft. A 'standing column' type arrangement was installed, with an electric submersible pump (6" Franklin VS14/20 with motor rated at $11 \mathrm{~kW}$ ) installed at a short distance below the (then) water level at $235 \mathrm{~m} \mathrm{bgl}$ (Athresh et al. 2015). As at Caphouse, the pumped water (at c. $14-15^{\circ} \mathrm{C}$ ) was passed through a mesh filter and then a sealed shell and tube heat exchanger arrangement, thermally coupled via a secondary circuit of heat transfer fluid to a Danfoss DHP-R $20 \mathrm{~kW}$ heat pump (Fig. 7). The thermally spent mine water at around $12-13{ }^{\circ} \mathrm{C}$ was returned, without atmospheric contact, via a reinjection main down the shaft to be released to the water column via a diffuser at $250 \mathrm{~m} \mathrm{bgl}$ (this arrangement is referred to as standing column Regime 1-Fig. 6). No net abstraction of mine water thus takes place at Markham (Athresh et al. 2015). The heat pump supplies hot water at $52-55^{\circ} \mathrm{C}$ to a buffer tank, which thereafter supplies hot water for space heating (via a combination of radiators, fan coil units and underfloor heating) to the Alkane on-site office complex. Return water to the heat pump is typically at c. $45-46^{\circ} \mathrm{C}$.

The overall efficiency of the system is compromised by the amount of electricity required to pump some $2 \mathrm{~L} \mathrm{~s}^{-1}$ of mine water up in excess of $200 \mathrm{~m}$. Around April 2014, Athresh et al. (2015) estimated the system COP (heat supplied divided by electricity consumption by heat pump and submersible pump, based on idealised heat pump characteristics and estimated minimum energy required for pumping) to be no greater than 2.7. Athresh et al. (2015) also predicted that a system COP of 3.95 could be achieved if the mine water level rose to within $15 \mathrm{~m}$ of the surface.

In January 2015, mine water levels had risen, allowing the entire standing column arrangement to be raised in the shaft (thus potentially saving on pumping costs). The pump was re-positioned at $170 \mathrm{~m} \mathrm{bgl}$, with the reinjection diffuser 
Fig. 6 a Graph showing rate of increase in mine water level in Markham No. 3 shaft, with b a superimposed section of the shaft, showing interconnections to other collieries and the arrangement of pump and reinjection return during pumping regime 1 , and $\mathbf{c}$ abbreviated section of the shaft, showing arrangement of pump and reinjection return during pumping regime 2. Modified from Burnside et al. (2016b)

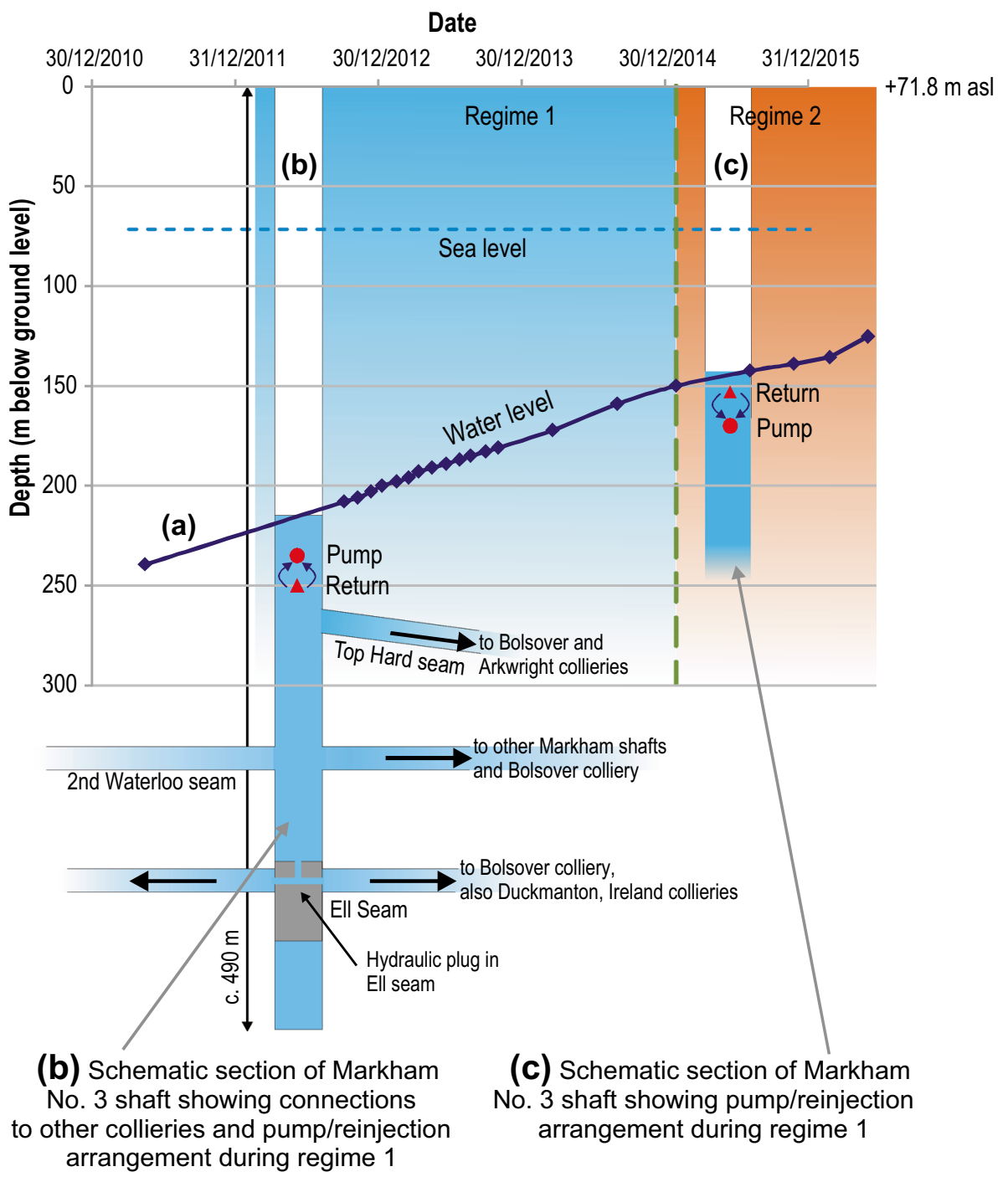

now being set $17 \mathrm{~m}$ above the pump at $153 \mathrm{~m} \mathrm{bgl} \mathrm{(known}$ as standing column Regime 2-Fig. 6). Following this, the pumped water temperature appears to have fallen somewhat to $13-14^{\circ} \mathrm{C}$. As at Caphouse, the mine water has been regularly sampled (Burnside et al. 2016b, Table 1) and the performance of the system monitored, since January 2015, using (1) a Kampstrup 602 Multical heat meter measuring the thermal energy supplied from the heat pump to the thermal buffer tank, (2) an identical heat meter measuring the amount of thermal energy extracted from the mine water and (3) two electric meters, one measuring the electrical power consumed by the heat pump unit and the other measuring the power supplied to the submersible pump. An actual system COP (heat output divided by electrical consumption by the heat pump and submersible pump) of 1.9 has recently been calculated. Despite the submersible pump being fitted with a frequency controller and being run at $43 \mathrm{~Hz}$ and $5.2 \mathrm{~kW}$ power, it is clear that the electricity consumption by the submersible pump is detrimental to the overall efficiency.

The gas engine generators at the site have to be pressed into service within a couple of minutes of the National Grid requesting additional power. Thus, the engines have to be pre-warmed to enable a start at short notice. Previously an electric heater was used to pre-warm the engines but, most recently, the system has been modified so that the heat pump also pre-warms the gas engines. Moreover, when the engines are running, the facility also exists for the gas engines to feed exhaust heat back into the buffer tank on the space heating circuit on the condenser side of the heat pump, negating the need for heat pump operation during such episodes and enhancing the overall COP of the system (although the gas engines are only typically operated every few days to provide peak load electricity).

It was initially assumed that the Markham No. 3 mine water would be rather saline and highly reducing (as the water degasses natural dissolved methane which 

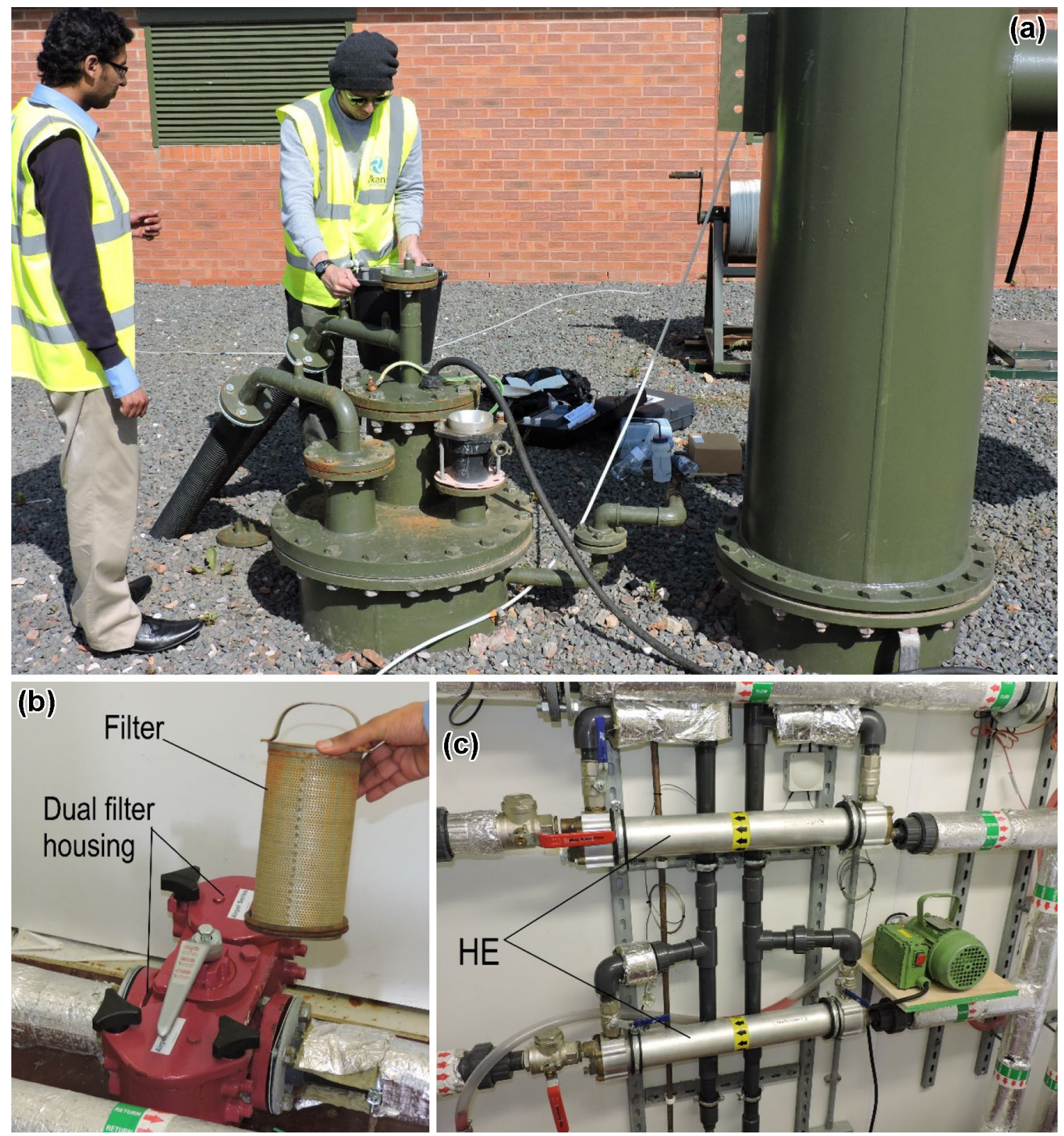

Fig. 7 Markham No. 3 Shaft heat pump system. a Two of the authors (AA and NB) at the shaft top; b mine water filter (relatively unclogged); $\mathbf{c}$ shell and tube heat exchangers, marked as HE (pump shown is used for filling and pressurising glycol circuit)

occasionally needs to be dispersed by air blowers in the shaft). During initial trial pumping of the shaft from 250-340 m depth, electrical conductivities in excess of $40,000 \mu \mathrm{S} \mathrm{cm} \mathrm{cm}^{-1}$, and ammoniacal nitrogen concentrations of $14 \mathrm{mg} \mathrm{L}^{-1}$ were recorded, with very low sulphate concentrations indicative of sulphate-reducing conditions (Burnside et al. 2016b).

Following the installation of the standing column Regime 1, the water quality was still relatively saline, with electrical conductivities of $20,000-25,000 \mu \mathrm{S} \mathrm{cm}{ }^{-1}$, dominated by sodium and chloride, but with $500-1700 \mathrm{mg}$
$\mathrm{L}^{-1}$ sulphate. Concentrations of 4-5 $\mathrm{mg} \mathrm{L}^{-1}$ ammoniacal nitrogen, 3-4 $\mathrm{mg} \mathrm{L}^{-1} \mathrm{Mn}$ and up to $9 \mathrm{mg} \mathrm{L}^{-1}$ methane all suggested broadly reducing conditions (although not necessarily sulphate reducing). Iron concentrations were typically $20-22 \mathrm{mg} \mathrm{L}^{-1}$, though occasionally falling to slightly below $4 \mathrm{mg} \mathrm{L}^{-1}$, and the iron appeared to be in its dissolved ferrous form. No problems were noted with clogging of the filters or heat exchangers with ochre deposits or other scale. This is presumed to be because iron remained reduced and soluble and was not exposed to atmospheric oxygen. 
Following the raising of the standing column arrangement (regime 2), the mine water quality changed substantially, suggesting that there is likely to be stratification of the water column within the mine shaft, with fresher, less reducing water occupying the uppermost portion. The electrical conductivity declined to $2000-3000 \mu \mathrm{S} \mathrm{cm}-1$ (although still $\mathrm{Na}-\mathrm{Cl}$ dominated), sulphate to a few $100 \mathrm{mg}$ $\mathrm{L}^{-1}$, ammonium and methane dropped to very low levels and nitrate was detected at $3-5 \mathrm{mg} \mathrm{L}^{-1}$. Manganese fell to $<100 \mu \mathrm{g} \mathrm{L}^{-1}$ and iron to $310-720 \mu \mathrm{g} \mathrm{L}^{-1}$. Significantly, the dissolved iron was less than the total iron, suggesting that, now, some iron oxidation and hydrolysis might be taking place in the shaft itself. This has not yet manifested itself as problems with ochre clogging of filters or heat exchangers, however, possibly due to the low total iron concentrations available.

To date, no problems of long-term decline of temperature, relating to thermal feedback of reinjected cool water to the abstraction pump, have been noted (possibly reflecting the low pumping rate relative to the volume and cross section of the shaft, or maybe reflecting some water movement within the shaft), nor has any tendency towards ochre (or other) clogging of filters or heat exchangers (Fig. 5).

\section{Caphouse, Yorkshire: closed-loop system}

As an alternative to the open-loop scheme described above, at Caphouse Colliery the Vaillant Geotherm VWS $101 / 210.5 \mathrm{~kW}$ heat pump has the additional possibility of sourcing its energy from a closed-loop heat exchanger submerged in aeration pond A1 (Fig. 3). Because pond A1 always contains mine water, even when Hope Shaft is not being pumped, the closed-loop system can be used at any time of the day. The water temperatures and levels are continuously logged in the 1st aeration pond (A1, logger 1 in Fig. 3), the balancing pond (B, logger 2), near the outlet of the sedimentation basins (S, logger 3) and near the outlet of the upper reed bed (R1, logger 4). A typical time series for one week in summer (August 2015) is shown in Fig. 8.

The water levels in the aeration pond clearly show the times of pumping (night and early morning) of Hope Shaft. During the daytime, there is little flow in the aeration pond and the water heats up, reaching a maximum of over $16{ }^{\circ} \mathrm{C}$ in early evening. Thereafter the water cools but drops, immediately when the Hope Shaft pumps are switched on, to a temperature a little above $14^{\circ} \mathrm{C}$ (the mine water temperature). In the deeper balancing pond (B), temperatures reach around $15^{\circ} \mathrm{C}$ during the day but as the Hope Shaft starts pumping, the warm water overflows from the aeration ponds into the balancing pond, causing a short-lived peak in temperature, which then drops off towards the mine water temperature. The temperature variation is even more subdued in the sedimentation pond. At the exit from the reed bed, however, the shallow slow water flow has been vulnerable to atmospheric temperature fluctuations and daytime temperatures of over $17^{\circ} \mathrm{C}$ are reached.

During the winter (Fig. 8), almost the opposite picture emerges. As the Hope Shaft starts pumping in the evening, the water temperature in the 1st aeration pond increases to a constant $14^{\circ} \mathrm{C}$ (the mine water temperature). After pumping ceases, the temperature drops slowly, depending on the air temperature. During the winter of 2015-16, however, the aeration pond seldom dropped below $11.5^{\circ} \mathrm{C}$. The balancing pond shows a similar pattern, but generally $0.5-1{ }^{\circ} \mathrm{C}$ cooler during pumping and several ${ }^{\circ} \mathrm{C}$ cooler when the Hope Shaft was not pumping. The sedimentation pond temperatures generally correspond to the balancing pond (B) but in a much more subdued form. As in summer, the reed bed outlet temperatures are much more susceptible to atmospheric interaction (heat losses during winter, especially at night).

The closed-loop heat exchanger is an NRS "Energy Blade 3K4" comprising four parallel $3 \mathrm{~m} \times 0.49 \mathrm{~m}$ heat exchange panels in 304 stainless steel (Fig. 9), giving a total heat exchange surface area of $11.8 \mathrm{~m}^{2}$, mounted on a frame and submerged in the 1st aeration lagoon (A1 in Fig. 3). The nominal heat exchange capacity is cited as $8 \mathrm{~kW}$ in standing water (Nuenta 2015), which makes it suitable for coupling to a $10.5 \mathrm{~kW}$ heat pump, which, at a COP of 4 would be extracting $10.5 \mathrm{~kW} \times 0.75=7.9 \mathrm{~kW}$ from the lagoon. The Energy Blade is coupled into the heat pump's heat transfer fluid circuit via insulated flow and return pipes. The entire system is filled with $20 \%$ propylene glycol-based Hydratech Thermox FPG heat transfer fluid. The relatively low percentage of anti-freeze was selected in order to reduce fluid viscosity in a relatively long hydraulic circuit, in the knowledge that the aeration lagoons maintain a temperature well above $10^{\circ} \mathrm{C}$ all year. The heat transfer fluid is circulated by the heat pump's source-side circulation pump. The system has worked very satisfactorily since installation and is preferred over the open-loop system (above) by the Caphouse museum staff for two reasons (1) it can be used at any time and is not dependent on the Hope Shaft pumping at the time of operation, (2) no mine water is passed through the heat exchange/heat pump system, removing issues with ochre clogging or clearing of filters. During operation, the glycol circuit typically runs with a temperature differential of $5^{\circ} \mathrm{C}$, with fluid entering from the Energy Blade at $10.4{ }^{\circ} \mathrm{C}$ and leaving the evaporator at $5.3^{\circ} \mathrm{C}$. The relatively high differential suggests, in turn, that the heat pump's circulation pump is somewhat undersized for the optimum flow rate.

Two thermal response tests have been carried out on the Energy Blade using a GeoCube ${ }^{\mathrm{TM}}$ test rig manufactured by Precision Geothermal (2016). This rig 

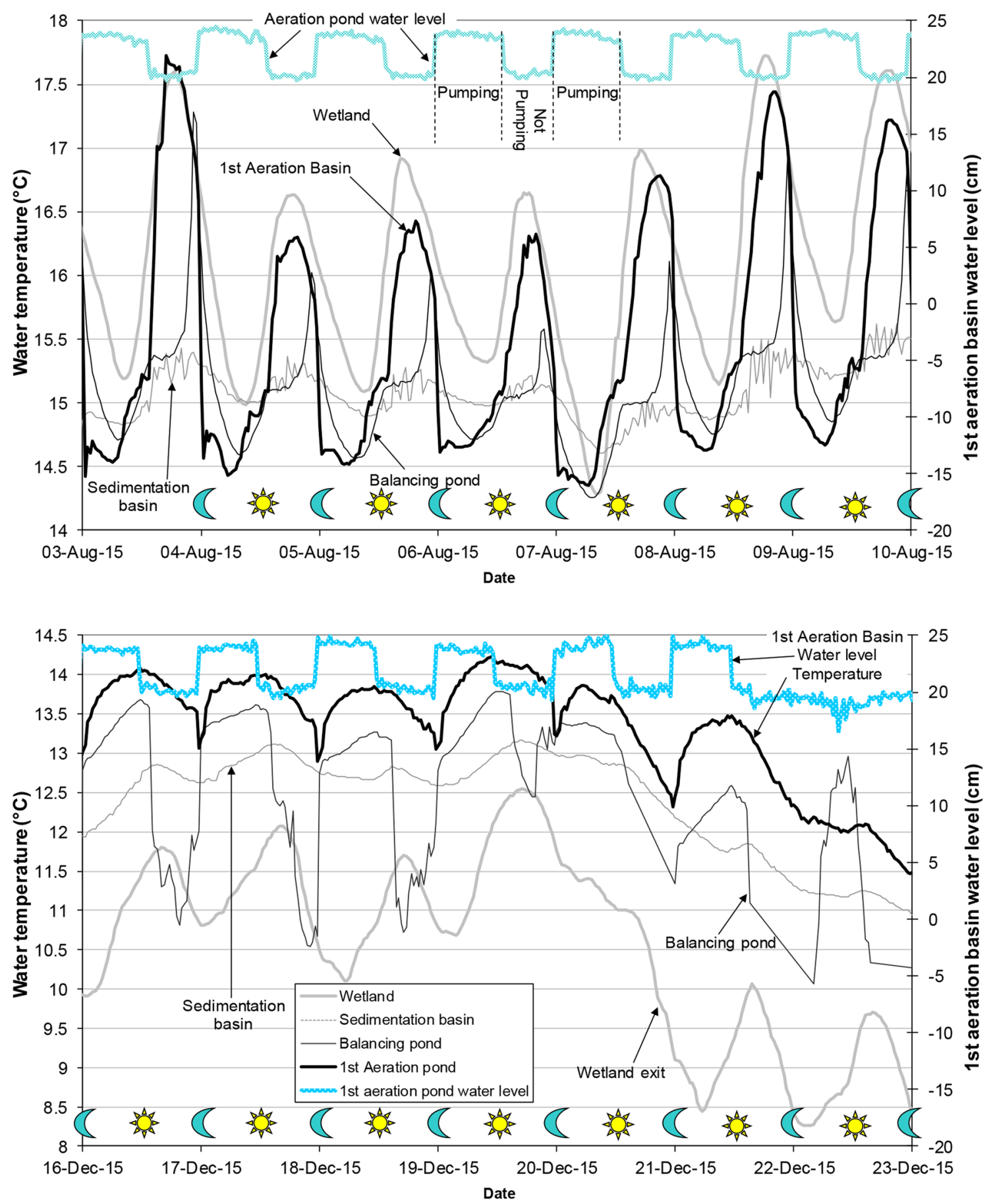

Fig. 8 A typical (top) summer (August 2015) and (bottom) winter (December 2015) week of water temperature fluctuations logged in loggers 1 (1st aeration pond, A1 in Fig. 3), 2 (balancing pond, B), 3 (sedimentation pond, S) and 4 (outlet from reed bed wetland R1)

essentially consists of a circulation pump, an array of electrical resistance heater elements capable of delivering up to c. $7.5 \mathrm{~kW}$ constant heat input, a flow meter and flow and return temperature sensors. The test rig is coupled to the Energy Blade via the heat transfer fluid in Caphouse mine water treatment system. The water level (cm head over logger sensor) shows periods of pumping of Hope Shaft. The crescent moons indicate night time (tick on $x$-axis at midnight) and suns indicate daytime

circuit (Fig. 4) and a constant heating load is applied. The rate of heat loss through the Energy Blade can thus be measured and its heat transfer coefficient determined. The first test was run on 8th-9th October 2015 (Fig. 10) and was run for just over $21 \mathrm{~h}$. Heat transfer coefficients 

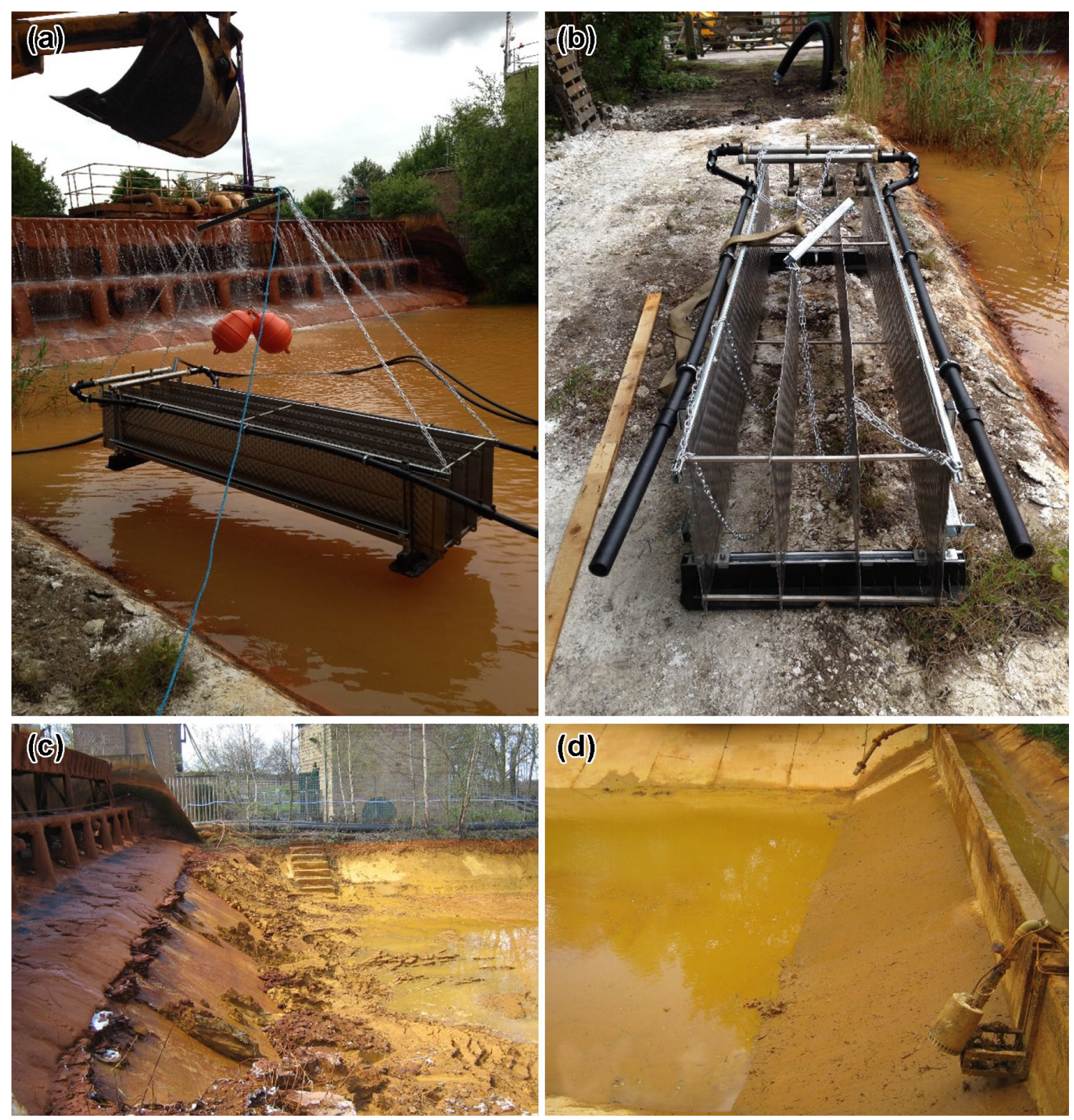

Fig. 9 The Energy Blade ${ }^{\mathrm{TM}}$ (b) prior to and (a) during installation in Caphouse No. 1 aeration lagoon; (c) aeration lagoon No. 1 prior to desludging (2013) and (d) aeration lagoon No. 2 following desludg-

of around $900-1000 \mathrm{~W} \mathrm{~K}^{-1}\left(76-85 \mathrm{~W} \mathrm{~m}^{-2} \mathrm{~K}^{-1}\right.$, given a cited heat exchange surface of $11.8 \mathrm{~m}^{2}$ ) were measured when the Hope Shaft was not pumping and the water in the aeration lagoon was immobile. When the Hope Shaft was pumping water through the aeration lagoon, however, the heat transfer coefficient increased to $1140-1180 \mathrm{~W} \mathrm{~K}^{-1}\left(97-100 \mathrm{~W} \mathrm{~m}^{-2} \mathrm{~K}^{-1}\right)$. This is significantly less than the heat transfer coefficient of $200 \mathrm{~W}$ $\mathrm{m}^{-2} \mathrm{~K}^{-1}$ claimed by Nuenta (2015) and is likely to be due to the GeoCube not achieving the minimum flow rate of $0.9 \mathrm{~L} \mathrm{~s}^{-1}$ recommended by the manufacturer (the rather small circulation pump of the GeoCube was only ing (2013). Photographs reproduced with kind permission of Mr Alan Chalkley, National Coal Mining Museum of England

able to maintain a flow rate of some $0.4 \mathrm{~L} \mathrm{~s}^{-1}$, which would likely have resulted in turbulent flow not being achieved within the heat exchanger and thus the heat exchange capacity being reduced). Another possibility was that the Energy Blade had become partially submerged in the ochre sediment which accumulates at the base of the aeration lagoon and this had interfered with the heat exchange capacity. In fact, the aeration lagoon was emptied and desludged during 20th-27th October 2015. The test was re-run on 27th-28th April 2016 (Fig. 11), to evaluate whether desludging has improved the heat transfer performance of the blade. In fact, the 

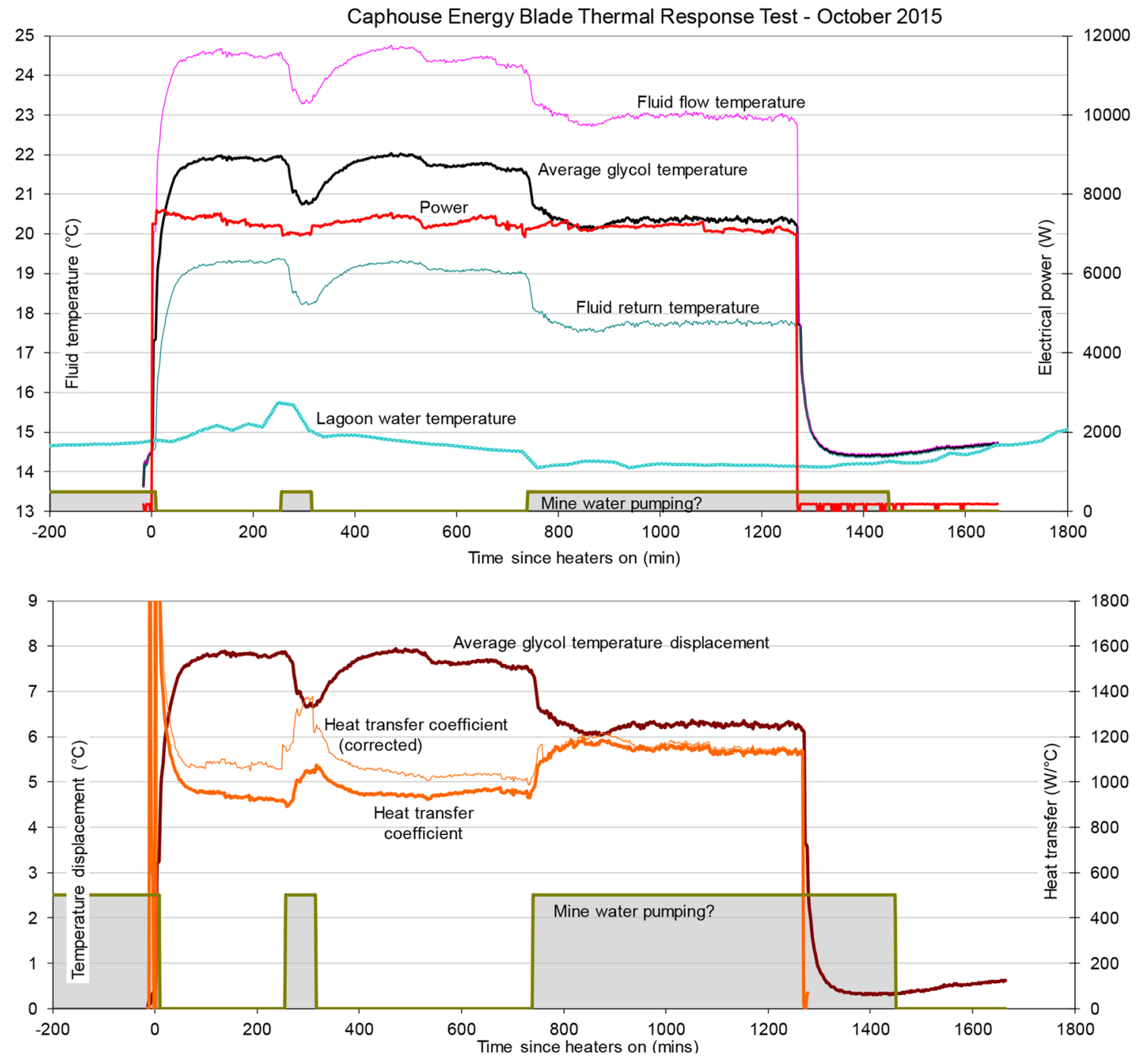

Fig. 10 Thermal response test on aeration lagoon heat exchanger, October 2015. The upper diagram shows the calculated electrical heater power $(W)$, the glycol flow and return temperatures, the average glycol temperature, the lagoon water temperature from logger 1 and whether the mine water was pumping (shaded on/off). The lower

heat transfer capacity appears to have decreased slightly in April 2016, although the exact values calculated depend on the assumptions about the baseline temperature of the mine water lagoon, which varies throughout the test. Given this uncertainty, there is no significant difference between the results of the two tests.

\section{Discussion and conclusions}

It is possibly best to sum up the findings of this paper as advantages and disadvantages associated with each of the options discussed: diagram shows the glycol temperature displacement, relative to a baseline of $14.1^{\circ} \mathrm{C}$, the calculated heat transfer coefficient, relative to a lagoon baseline of $14.1^{\circ} \mathrm{C}$, a "corrected" heat transfer coefficient relative to the actual logged lagoon temperature, and whether the mine water was pumping (on/off)

\section{Open-loop systems}

\section{Advantage: scalable}

Open-loop schemes can be up-scaled simply by adding additional heat exchange capacity (and treatment capacity/reinjection boreholes, if necessary). The ultimate limit on the heat that can be extracted is simply (a) the quantity of mine water that is pumped or discharged and (b) the temperature differential that can be achieved across a heat exchanger. It is not coincidental that the largest mine water heat pump schemes in the UK (Egremont, Cumbria—only a pilot scheme, of $103 \mathrm{~kW}$, Banks 
Caphouse Energy Blade Thermal Response Test - April 2016
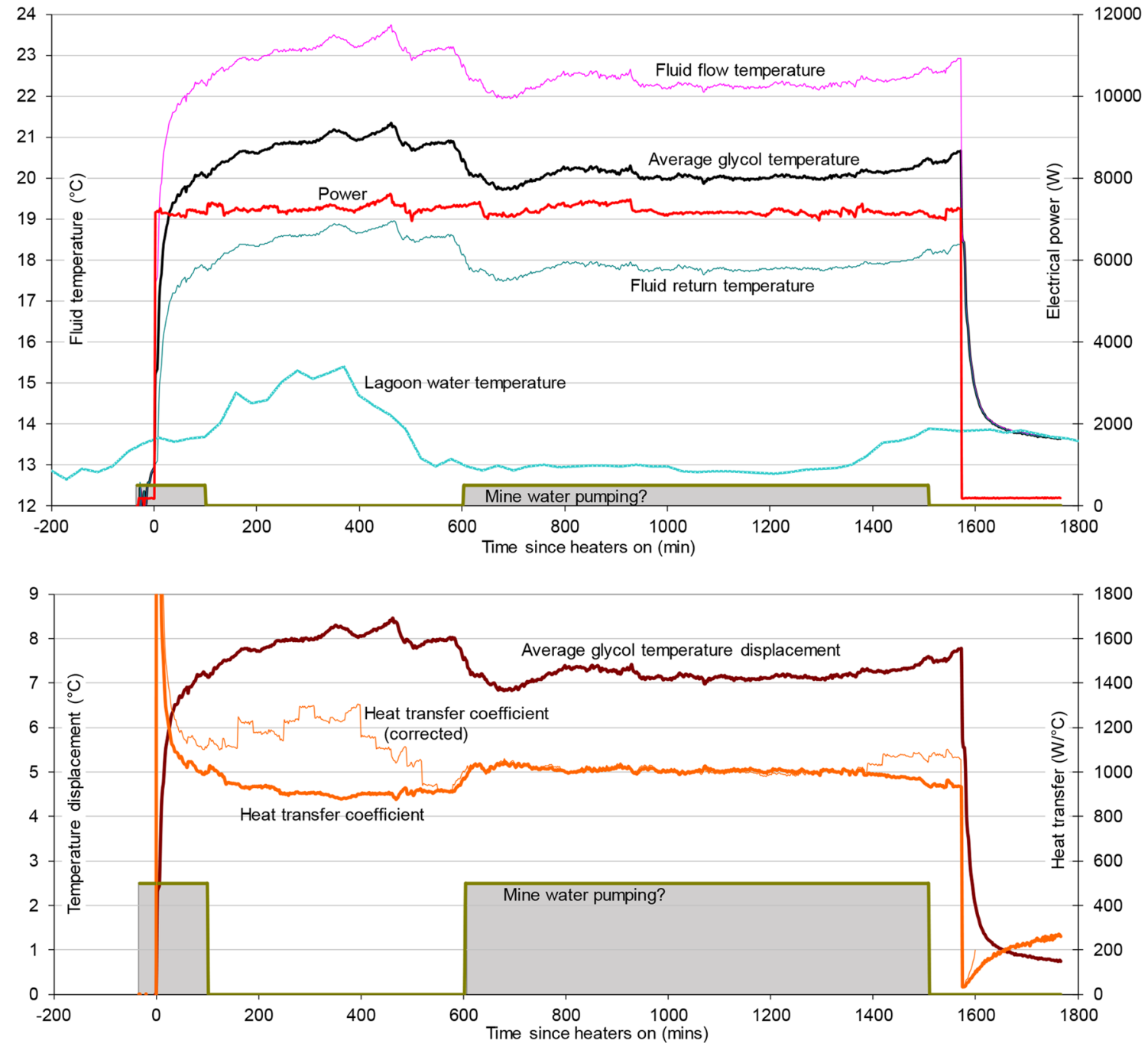

Fig. 11 Thermal response test on aeration lagoon heat exchanger, April 2016. The upper diagram shows the calculated electrical heater power $(W)$, the glycol flow and return temperatures, the average glycol temperature, the lagoon water temperature from logger 1 and whether the mine water was pumping (shaded on/off). The lower diagram shows the glycol temperature displacement, relative to a baseline of $12.9^{\circ} \mathrm{C}$, the calculated heat transfer coefficient, relative to a lagoon baseline of $12.9^{\circ} \mathrm{C}$, "corrected" heat transfer coefficient relative to the actual logged lagoon temperature, and whether the mine water was pumping (on/off). In this test, the lagoon warmed

et al. in press) and in the world (MW-scale schemes at Mieres, Spain and Heerlen, Netherlands) are all openloop schemes.

\section{Disadvantage: risk of chemical (ochre) precipitates}

The Coal Authority's Dawdon mine water heat pump scheme (Watson 2012; Bailey et al. 2013) found that passing iron-rich aerated mine water through a heat exchanger led to very rapid ochre clogging. In the case of Dawdon, significantly naturally during the day (when the mine water was not being pumped): this led to an apparent increase in heat transfer coefficient due to the decreased temperature differential between the heat exchange fluid and the lagoon water. The "corrected" heat transfer coefficient may, however, be an overestimate, if the logger (which is installed close to the lagoon sides and at shallow depth) is not representative of the deeper, probably cooler, water surrounding the heat exchanger. The "uncorrected" heat transfer coefficient may thus be more reliable

this was solved using raw, unaerated mine water. This supports the observations and modelling work of Banks et al. (2009), which indicated that chemically reducing, ironrich mine water can be used in heat exchange systems provided that it is not allowed to come into contact with atmospheric oxygen (or other oxidising agents), such that the iron remains in its soluble ferrous $\left(\mathrm{Fe}^{2+}\right)$ form (this conclusion is also supported by research into ochre clogging of land drainage systems-Abeliovich 1985). The observations from the LoCAL study sites also support 
this hypothesis-for example, the fact that the Markham No. 3 system operated under Regime 1 with no serious clogging issues, despite the relatively high reduced iron concentrations.

However, the LoCAL project seems to have demonstrated that not all mine waters are sufficiently chemically reducing to rely on iron always being present in its ferrous form. Indeed, there appears to be a subset of coal mine waters where oxidation of iron has commenced in the underground workings or shafts, such that ochre particles can be observed in the raw water, or where ochre clogging occurs, even where access to the atmosphere is precluded in the surface headworks (Caphouse, Shettleston). This can be diagnosed by analysing the ratio of total to ferrous iron in water analyses or by examining on-site filters (e.g. used for water sampling) for ochre particles. The presence of modest quantities of ochre particles (e.g. Shettleston) does not necessarily render a heat exchange scheme unworkable, and can be managed by a degree of maintenance. Where reinjection is practised, however, the presence of even small amounts of particulate matter can lead to a decline in the reinjection efficiency with time.

As regards mineralogical composition, ochre collected from the Caphouse mine water treatment basins was analysed by X-Ray Diffraction; although calcite was detected as a component, no prominent iron mineral peaks were noted, leading to the inference that the ochre largely comprises amorphous ferric hydroxide. Iron deposits from plate heat exchangers of the Spanish Barredo site were also found to be mainly amorphous ferric hydroxide, with a $6.3 \% \mathrm{CaCO}_{3}$ content, minor Mn-oxide content, and also with a detectable goethite $(\alpha-\mathrm{FeOOH})$ component (Loredo et al. 2017). Ochre deposits from the interior of the mine water pipe at the Scottish Shettleston scheme were also found to contain goethite.

In the future, the LoCAL project plans to experiment with dosing the mine waters with sodium bisulphite $\left(\mathrm{NaHSO}_{3}\right)$ or sodium dithionite $\left(\mathrm{Na}_{2} \mathrm{~S}_{2} \mathrm{O}_{4}\right)$ prior to heat exchange, in an attempt to maintain iron in reduced form in solution (Dudeney et al. 2003). These reducing agents can be regarded as relatively environmentally benign, oxidising to form a solution of sodium and sulphate.

\section{Disadvantage: difficulties in disposing of thermally spent water}

While, in theory, the reinjection of iron-rich mine water is feasible, via a thorough understanding of chemistry (as at Heerlen, Netherlands), some difficulties in reinjection have been experienced at two Scottish schemes (Banks et al. 2009), due to the oxidation of dissolved iron and/or the presence of ochre particulates in the raw water. Thus, large open-loop mine water heat pump schemes will often be best suited to waters which (a) are already pumped for regional mine water management purposes and which are already treated prior to discharge to the environment (i.e. no additional pumping or treatment costs-e.g. Caphouse), or (b) which have low enough iron concentrations (and have good enough quality otherwise) that they can be disposed of directly to a surface watercourse (e.g. Egremont, Cumbria and Mieres, Spain), or, failing that, (c) are of reducing chemical quality and where pre-oxidised ochre and other particles are absent, such that reinjection can be practised.

\section{Closed-loop systems}

\section{Advantage: does not depend on mine water pumping}

Although the LoCAL project's experiences at Caphouse indicate that a flow of mine water over a submerged heat exchanger does increase its heat transfer capacity, submerged closed-loop heat exchangers (in mines or in treatment basins) do not require a constant flow of mine water to function. They can thus be operated independently of any mine water pumping regime.

\section{Advantage: managed fluid quality}

No mine water is pumped, reinjected or circulated through heat exchangers/pumps in a closed-loop scheme. The fluid circulated is a heat transfer fluid of controlled composition (usually based on a solution of glycol). This obviates any issues with heat exchanger clogging or serious corrosion. On the other hand, it has been noted at Caphouse that the submerged heat exchanger becomes progressively fouled by accumulating ochre deposits in the aeration basin. We have, however, not been able to demonstrate that this, in itself, adversely affects heat capacity (the underperformance noted was likely due to inadequate heat transfer fluid flow rates).

\section{Disadvantage: slightly less efficient}

It can be seen, at Caphouse, that while the open-loop mine water scheme is based on mine water at $14^{\circ} \mathrm{C}$, the closedloop scheme requires a temperature differential to absorb heat from the lagoon to the heat transfer fluid. Thus, the fluid returns from the lagoon to the evaporator typically at around $10.4{ }^{\circ} \mathrm{C}$. This (together with the parasitic power required to circulate the heat transfer fluid) would be expected to result is a modestly lower heat pump efficiency.

\section{Disadvantage: less readily scalable}

Although, in theory, one could multiply the number of submerged heat exchangers in the aeration pond to 
increase the heat extraction, the amount of installed hardware could soon become unmanageable. For example, the Energy Blade extracts some $8 \mathrm{~kW}$ nominal heat capacity. To abstract the total potential of some $730 \mathrm{~kW}$ (Eq. 5) would require some 91 units. While a single unit can easily be lifted or moved when the aeration basin requires desludging of accumulated ochre, tens of units would undoubtedly prove off-putting to museum maintenance staff (it should, however, be noted that successful MW-scale closed-loop heat exchanger projects have been installed in very large natural lakes and reservoirs, which have no need for desludging or periodic removal, such as at Kings Mill Hospital, Mansfield, UK-Banks 2012).

\section{Standing column systems}

Advantage: may avoid licencing issues, need for treatment

Experiences at Markham No. 3 would suggest that standing column systems can work very successfully if the heat loads are modest. At Markham, very little additional infrastructure was required (submersible pump, controls, rising main, recharge main, heap exchangers, heat pump), given that the deep, large diameter open shaft already exists. No reinjection boreholes, no water treatment (other than venting of methane) and no surface disposal facilities were required. Under some legislative regimes, it may be possible to argue that, as no net abstraction is taking place and as water is being returned to the ground at the same quality as that abstracted, then no abstraction licences or discharge consents are necessary. This will, however, depend on the legal framework in each individual country.

\section{Disadvantage: may not be scaleable}

The modest $20 \mathrm{~kW}$ scheme at Markham appears to work very well, if one disregards the rather large parasitic submersible pump power caused by the deep water level. The larger $(103 \mathrm{~kW})$ pilot scheme at Egremont (Banks et al. 2017) also successfully operated for a short trial period. However, monitoring of temperatures during the Egremont trial suggested that the heat extractable by a pure standing column arrangement might be limited to no more than $100 \mathrm{~W} \mathrm{~m}^{-1}$ (or several tens of $\mathrm{kW}$ for a typical deep mine shaft of several $100 \mathrm{~m}$ depth). If natural advection is occurring within the shaft, however, replenishing the thermal resources, significantly greater heat yields might be available.

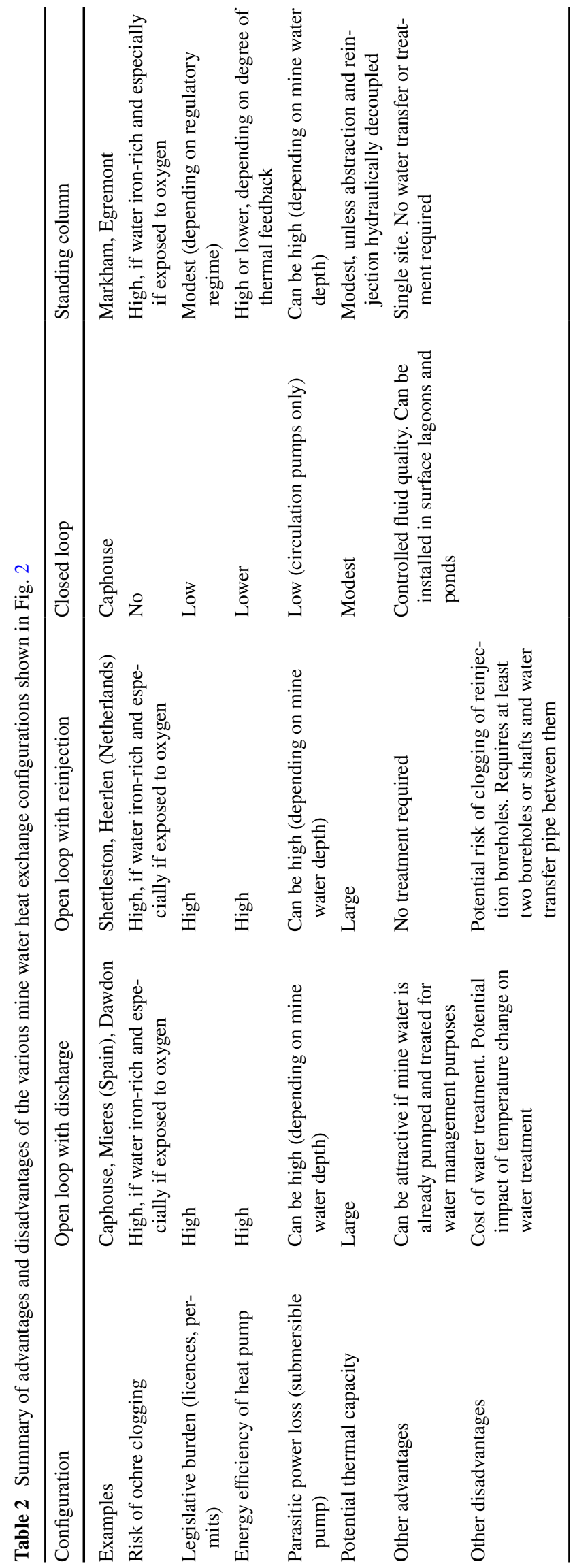




\section{Concluding statement}

The LoCAL project has successfully demonstrated the use of the four main mine water heat exchange configurations (open loop with discharge to surface water, open loop with reinjection, closed loop and standing column). Of these, the modest closed-loop scheme at Caphouse and standing column scheme at Markham have proved least problematic to operate (fewest problems with ochre clogging). The relative advantages and disadvantages of the schemes are summarised in Table 2. Although energy efficiency data are still being collected, the open-loop schemes may prove to be the more efficient schemes and are also likely to prove the most up-scalable. Among the outstanding issues that need to be investigated are:

1. can mine waters be successfully chemically dosed with environmentally benign reducing agents to hinder the oxidation and precipitation of ferric iron and manganese?

2. will altering the temperature of mine water (by heat extraction or rejection) adversely or favourably affect the efficiency of mine water treatment processes such as those at Caphouse (e.g. solubility of $\mathrm{O}_{2}, \mathrm{CO}_{2}$, rates of oxidation, hydrolysis, ochre nucleation and aggregation, rates of settlement, rate of growth of reeds in reed beds-Raftery 2016)?

Acknowledgements The work reported in this paper was funded as part of the Low-Carbon After-Life (LoCAL) project under the European Commission Research Fund for Coal and Steel Grant RFCRCT-2014-00001. The information on Shettleston is published by kind permission of the Shettleston Housing Association. We also wish to thank Dr. W. George Darling of the British Geological Survey for carrying out dissolved gas analyses from Caphouse and Markham (Table 1) and Drs Claire Wilson and Jaime Toney of the University of Glasgow for XRD analysis of ochre from Caphouse and Shettleston.

Open Access This article is distributed under the terms of the Creative Commons Attribution 4.0 International License (http:// creativecommons.org/licenses/by/4.0/), which permits unrestricted use, distribution, and reproduction in any medium, provided you give appropriate credit to the original author(s) and the source, provide a link to the Creative Commons license, and indicate if changes were made.

\section{References}

Abeliovich A (1985) Avoiding ochre deposits in soil drainage pipes. Agric Water Manage 10:327-334. doi:10.1016/0378-3774(85)90021-6

Athresh AP, Al-Habaibeh A, Parker K (2015) Innovative approach for heating of buildings using water from a flooded coal mine through an open loop based single shaft GSHP system. Energy Procedia 75:1221-1228. doi:10.1016/j.egypro.2015.07.162
Athresh AP, Amin Al-Habaibeh A, Parker K (2016) The design and evaluation of an open loop ground source heat pump operating in an ochre-rich coal mine water environment. Int J Coal Geol 164:69-76. doi:10.1016/j.coal.2016.04.015

Bailey MT, Moorhouse AML, Watson I (2013) Heat extraction from hypersaline mine water at the Dawdon mine water treatment site. In: Tibbett M, Fourie AB, Digby C (eds) Proceedings of the conference "Mine Closure 2013", Eden Centre, Cornwall. Australian Centre for Geomechanics, UK, pp 559-570

Banks D (1997) Hydrogeochemistry of Millstone Grit and Coal Measures groundwaters, south Yorkshire and north Derbyshire, UK. Q J Eng Geol 30:237-256. doi:10.1144/GSL. QJEG.1997.030.P3.06

Banks SB (2007) The UK Coal Authority minewater-treatment scheme programme: performance of operational systems. Water Environ J 17(2):117-122. doi:10.1111/j.1747-6593.2003. tb00444.x

Banks D (2012) An introduction to thermogeology: ground source heating and cooling, 2nd edition. Wiley, Chichester, p 526

Banks D (2016) Making the red one green-renewable heat from abandoned flooded mines. In: Proc. 36th Annual Groundwater Conference, International Association of Hydrogeologists, Irish Group. "Sustaining Ireland's Water Future: The Role of Groundwater", 12th-13th April 2016, Tullamore, Co. Offaly, Ireland, Session VI, pp 1-9

Banks SB, Banks D (2001) Abandoned mines drainage: impact assessment and mitigation of discharges from coal mines in the UK. Eng Geol 60:31-37. doi:10.1016/S0013-7952(00)00086-7

Banks D, Younger PL, Arnesen RT, Iversen ER, Banks SB (1997a) Mine water chemistry: the good, the bad and the ugly. Environ Geol 32:157-174. doi:10.1007/s002540050204

Banks D, Burke SP, Gray CG (1997b) Hydrogeochemistry of coal mine drainage and other ferruginous waters in north Derbyshire and south Yorkshire, UK. Q J Eng Geol 30:257-280. doi:10.1144/GSL.QJEG.1997.030.P3.07

Banks D, Skarphagen H, Wiltshire R, Jessop C (2003) Mine water as a resource: space heating and cooling via use of heat pumps. Land Contam Reclam 11(2):191-198. doi:10.2462/09670513.814

Banks D, Skarphagen H, Wiltshire R, Jessop C (2004) Heat pumps as a tool for energy recovery from mining wastes. In: Gieré R, Stille $P$ (eds) Energy, waste and the environment: a geochemical perspective, vol 236. Geological Society Publishing House, Bath, pp 499-513. doi:10.1144/GSL.SP.2004.236.01.27

Banks D, Fraga Pumar A, Watson I (2009) The operational performance of Scottish minewater-based ground source heat pump systems. Q J Eng Geol Hydrogeol 42:347-357. doi:10.1144/1470-9236/08-081

Banks D, Steven J, Berry J, Burnside N, Boyce A (2017) A combined pumping test and heat extraction/recirculation trial in an abandoned haematite ore mine shaft, Egremont, Cumbria, UK. Sustain Water Resourc Manag (to be published)

Bayless ER, Olyphant GA (1993) Acid-generating salts and their relationship to the chemistry of groundwater and storm runoff at an abandoned mine site in southwestern Indiana, USA. J Contam Hydrol 12(4):313-328. doi:10.1016/0169-7722(93)90003-B

Bracke R, Bussmann G (2015) Heat-storage in deep hard coal mining infrastructures. In: Proceedings World Geothermal Congress 2015, Melbourne, Australia, 19th-25th April 2015

Brown I, Goodchild J (1979) The coal mines of the Flockton area, near Horbury, West Yorkshire. Bull Peak Dist Mines Hist Soc 7(3):169-173. http://www.pdmhs.com/docs/default-source/bulletins/bulletin-7-3/bulletin-7-3 - the-coal-mines-of-the-flockton-area-near-hor.pdf?sfvrsn=2. Accessed 10th Jan 2017

Burke T (1998) Report of the relationship of the proposed development at Glenalmond Street, Shettleston and nearby abandoned 
mine workings. Report 3.256 by Tom Burke Mining Consultant for Enconsult, January 1998

Burnside NM, Banks D, Boyce AJ (2016a) Sustainability of thermal energy production at the flooded mine workings of the former Caphouse Colliery, Yorkshire, United Kingdom. Int J Coal Geol 164:85-91. doi:10.1016/j.coal.2016.03.006

Burnside NM, Banks D, Boyce AJ, Athresh A (2016b) Hydrochemistry and stable isotopes as tools for understanding the sustainability of thermal energy production from a 'standing column' heat pump system: Markham Colliery, Bolsover, Derbyshire, UK. Int J Coal Geol 165:223-230. doi:10.1016/j. coal.2016.08.021

Burrows JE, Peters SC, Cravotta CA III (2015) Temporal geochemical variations in above- and below-drainage coal mine discharge. Appl Geochem 62:84-95. doi:10.1016/j.apgeochem.2015.02.010

Crook T (1912) On the frequent occurrence of ankerite in coal. Mineral Mag 16(75):219-223. doi:10.1180/minmag.1912.016.75.06

DOE (2015) Geothermal retrofit of Illinois National Guard's state headquarters Building. DOE award DE-EE0003002, Final Technical Report, 27th April 2015. 30 pp. doi:10.2172/1179248. http://www.osti.gov/scitech/biblio/1179248/. Accessed 4th May 2016

Dold B (2017) Acid rock drainage prediction: a critical review. J Geochem Explor 172:120-132. doi:10.1016/j.gexplo.2016.09.014

Dudeney B, Demin O, Tarasova I (2003) Control of ochreous deposits in mine water treatment. Land Contam Reclam 11(2):259-266. doi: $10.2462 / 09670513.823$

Eden RA, Stevenson IP, Edwards MA (1957) The geology of the country around Sheffield. Memoirs of the Geological Survey of Great Britain, Geological Sheet 100, Her Majesty's Stationery Office (HMSO), London

Faraldo Sanchez M (2007) Thermal balance of minewater treatment lagoons and wetlands. MSc thesis in Environmental Engineering, School of Civil Engineering and Geosciences, University of Newcastle, June 2007

Ferket HLW, Laenen BJM, Van Tongeren PCH (2011) Transforming flooded coal mines to large-scale geothermal and heat storage reservoirs: what can we expect? In: Rüde RT, Freund A, Wolkersdorfer C (eds), Proc. IMWA Congress 2011 (Aachen, Germany), Mine water-managing the challenges, pp 171-175

Grundl T, Delwiche J (1993) Kinetics of ferric oxyhydroxide precipitation. J Contam Hydrol 14(1):71-87. doi:10.1016/0169-7722(93)90042-Q

Gzyl G, Banks D (2007) Verification of the "first flush" phenomenon in mine water from coal mines in the Upper Silesian Coal Basin, Poland. J Contam Hydrol 92:66-86. doi:10.1016/j. jconhyd.2006.12.001

Gzyl G, Banks D, Younger PL, Głodniok M, Burnside N, Garzon B, Skalny A (2016). Low Carbon After-Life-overview and first results of project LoCAL. In: Drebenstedt C, Paul M (eds) Proc. IMWA conference 2016 (Leipzig, Germany), mining Meets water-conflicts and solutions, pp 593-599. http://www.imwa. info/imwaconferencesandcongresses/proceedings/298-proceedings-2016.html. Accessed Aug 2016

Hall A, Scott JA, Shang H (2011) Geothermal energy recovery from underground mines. Renew Sustainable Energy Rev 15:916-924. doi:10.1016/j.rser.2010.11.007

Hawkes L, Smythe JA (1935) Ankerites of the Northumberland coal-field. Mineral Mag 24(149):65-75. doi:10.1180/ minmag. 1935.024.149.03

Healeyhero (2015) Markham Colliery-1973. Background information-the colliery. HealeyHero website http://www.healeyhero. co.uk/rescue/pits/markham/markham_73_1.htm. Accessed 24th Oct 2015

INWATCO (2005a) Integrated Water Management In Former Coal Mining Regions: Guidance to Support Strategic Planning.
Report available at http://www.wise-rtd.info/sites/default/files/d2007-07-03-good_practice_guide.pdf. Accessed 24th May 2016

INWATCO (2005b) Integrated Water Management In Former Coal Mining Regions: Non-technical summary. http://ec.europa.eu/ environment/life/project/Projects/index.cfm?fuseaction=home. showFile\&rep=file\&fil=LIFE02_ENV_UK_000140_LAYMAN.pdf. Accessed 24th May 2016

Janson E, Gzyl G, Banks D (2009) The occurrence and quality of mine water in the Upper Silesian Coal Basin, Poland. Mine Water Environ 28:232-244. doi:10.1007/s10230-009-0079-3

Janson E, Boyce AJ, Burnside NM, Gzyl G (2016) Preliminary investigation on temperature, chemistry and isotopes of mine water pumped in Bytom geological basin (USCB Poland) as a potential geothermal energy source. Int J Coal Geol 164:104-114. doi:10.1016/j.coal.2016.06.007

Jardón S, Ordóñez MA, Alvarez R, Cienfuegos P, Loredo J (2013) Mine water for energy and water supply in the Central Coal Basin of Asturias (Spain). Mine Water Environ 32:139-151. doi:10.1007/s10230-013-0224-x

Jessop A (1995) Geothermal energy from old mines at Springhill, Nova Scotia, Canada. In: Barbier E (ed) Proc. World Geothermal Congress 1995 (Florence, Italy, 18th-31st May 1995), International Geothermal Association, pp 463-468

Jessop AM, Macdonald JK, Spence H (1995) Clean energy from abandoned mines at Springhill, Nova Scotia. Energy Sources 17:93-106

Korb MC (2012) Minepool geothermal in Pennsylvania. Presentation at the 2012 PA AML Conference, New Frontiers in Reclamation, August 2nd-4th 2012, State College, Pennsylvania, USA. http://2012.treatminewater.com/KorbMinepoolGeothermal2012. pdf. Accessed 6th Feb 2016

Kruse N (2007) Simulation of hydrogeochemical processes in abandoned underground mines. $\mathrm{PhD}$ thesis, School of Civil Engineering and Geosciences, University of Newcastle, June 2007

Lake RD, Hough EH (ed) (2006) The Pennine lower and middle coal measures formations of the Barnsley district. British Geological Survey Internal Report, IR/06/135, p 47

Loredo J, Ordóñez A, Jardón S, Álvarez R (2011) Mine water as geothermal resource in Asturian coal mining basins (NW Spain). In: Rüde RT, Freund A, Wolkersdorfer C (eds), Proc. IMWA Congress 2011 (Aachen, Germany), mine water-managing the challenges, pp 177-181

Loredo C, Ordóñez A, Garcia-Ordiales E, Álvareza R, Roqueñia N, Cienfuegosa P, Peña A, Burnside NM (2017) Hydrochemical characterization of a mine water geothermal energy resource in NW Spain. Sci Total Environ 576:59-69. doi:10.1016/j. scitotenv.2016.10.084

Malolepszy Z, Demollin-Schneiders E, Bowers D (2005) Potential use of geothermal mine waters in Europe. In: Proceedings World Geothermal Congress 2005, Antalya, Turkey, 24-29 April 2005

Michel FA (2009) Utilization of abandoned mine workings for thermal energy storage in Canada. Proceedings Effstock 2009 Paper 105, Session 11_1. https://talon.stockton.edu/eyos/energy_studies/content/docs/effstock09/Session_11_1_Case\%20studies_ Overviews/105.pdf. Accessed Jan 2017

Minewater Project (2008) Minewater as a renewable energy resource: an information guide based on the Minewater Project and the experiences at pilot locations in Midlothian and Heerlen. The Minewater Project (INTERREG)

Nuenta (2015) Energy blade 3K4: energy blade installation instructions. Nuenta Ltd., Cannock. http://nuenta.com/viewproduct. asp?pid=109. Accessed 1st June 2016

Ordóñez A, Jardón S, Álvarez R, Andrésa C, Pendása F (2012) Hydrogeological definition and applicability of abandoned coal mines as water reservoirs. J Environ Monit 14:2127-2136. doi:10.1039/C2EM11036A 
Precision Geothermal (2016) GeoCube ${ }^{\mathrm{TM}}$ website. http://precisiongeothermal.com/geocube.htm. Precision Geothermal LLC, Maple Plain, USA. Accessed 26th May 2016

Preene M, Younger PL (2014) Can you take the heat?-geothermal energy in mining. Mining Technol 123:107-118. doi:10.1179/17 43286314Y.0000000058

Raftery A (2016) An assessment of ferrous iron oxidation, hydrolysis and precipitation as a function of temperature. MSc thesis in Hydrogeology, School of Geography, Earth and Environmental Sciences, University of Birmingham, August 2016

Ramos EP, Breede K, Falcone G (2015) Geothermal heat recovery from abandoned mines: a systematic review of projects implemented worldwide and a methodology for screening new projects. Environ Earth Sci 73:6783-6795. doi:10.1007/ s12665-015-4285-y

Rostov Regional Government (2011) Новошахтинск согреют теплом шахтных вод (Novoshakhtinsk heats with warm mine water-in Russian). http://minjkh.donland.ru/Data/Sites/5/ media/jkh/file/publikacii/innov.pdf. Accessed 6th Feb 2016

Sheppard TH (2005) A stratigraphical framework for the Upper Langsettian and Duckmantian of the East Pennine coalfields. British Geological Survey Internal Report IR/05/070. British Geological Survey, Keyworth, Nottinghamshire, UK

Tokarz M, Mucha W (2013) Wykorzystanie energii geotermalnej pochodzącej z odwadniania zakładów górniczych, na przykładzie rozwiązań zastosowanych w SRK S.A. Zakładzie CZOK w Czeladzi. Technika Poszukiwań Geologicznych 52:103-114

Tweedie S (2014) Maximising geoexchange performance with abandoned mines. In: Proc. 11th IEA Heat Pump Conference, 12-16 May 2014, Montreal (Quebec) Canada. Poster P.4.1. http://etkhpcorderapi.extweb.sp.se/api/file/1237. Accessed Jan 2017

Verhoeven R, Willems E, Harcouët-Menou V, De Boever E, Hiddes L, Op't Veld P, Demollin E (2014) Minewater 2.0 project in Heerlen the Netherlands: transformation of a geothermal mine water pilot project into a full scale hybrid sustainable energy infrastructure for heating and cooling. Energy Procedia 46:5867. doi:10.1016/j.egypro.2014.01.158

Watson I (2012) Dawdon mine water heat pump trial. Proc. IEA Heat Pump Programme Workshop, London 13th November 2012. http://web.ornl.gov/sci/ees/etsd/btric/usnt/03IWatson.pdf. Accessed 9th Feb 2016

Watzlaf GR, Ackman TE (2006) Underground mine water for heating and cooling using geothermal heat pump systems. Mine Water Environ 25:1-14. doi:10.1007/s10230-006-0103-9

Younger PL (2000) Predicting temporal changes in total iron concentrations in groundwaters flowing from abandoned deep mines: a first approximation. J Contam Hydrol 44(1):47-69. doi:10.1016/ S0169-7722(00)00090-5 